\begin{tabular}{c} 
Review of \\
ECONOMICS \\
and \\
INSTITUTIONS \\
\hline
\end{tabular}

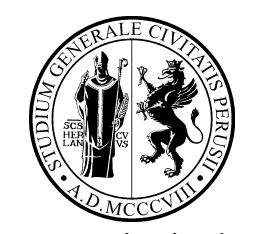

www.rei.unipg.it

\title{
The Euro and Structural Reforms
}

\author{
Alberto Alesina ${ }^{\varpi}$ \\ Harvard University
}

\author{
Silvia Ardagna \\ Harvard University
}

\author{
Vincenzo Galasso \\ IGIER, Bocconi \\ University
}

\begin{abstract}
This paper investigates whether or not the adoption of the Euro has facilitated the introduction of structural reforms, defined as deregulation in the product markets and liberalization and deregulation in the labor markets. After reviewing the theoretical arguments that may link the adoption of the Euro and structural reforms, we investigate the empirical evidence. We find that the adoption of the Euro has been associated with an acceleration of the pace of structural reforms in the product market. The adoption of the euro does not seem to have accelerated labor market reforms in the "primary labor market"; however, the run up to the Euro adoption seems to have been accompanied by wage moderation. We also investigate issues concerning the sequencing of goods and labor market reforms.
\end{abstract}

JEL classification: E63, J41,L51

Keywords: Euro, structural reforms, deregulation, European labor markets

Prepared for the NBER Conference on Europe and the Euro, October 17 \& 18, 2008. We thank Olivier Blanchard, Francesco Caselli, Francesco Giavazzi, Guido Tabellini, Silvana Tenreyro and our discussant Otmar Issing for very useful comments and Carlo Prato and Roberto Robatto for excellent research assistantship. This paper was previously published in the book "Europe and the Euro", edited by A. Alesina and F. Giavazzi, The University of Chicago Press, 2010. Its reproductions here has been authorized by the University of Chicago Press (Permission n. 0049534742).

\section{Introduction}

One of the arguments in favor of the introduction of the common currency area in Europe was that it would have pressured member countries to improve their macroeconomic policy and pursue "structural reforms", the latter being defined as labor and product markets' liberalization and deregulation. Has it worked? Have members of the Euro

$\square$ Corresponding author. Address: Department of Economics, Harvard University, Cambridge, MA 02138. (Phone: 001-617-4958388, Fax: 001-617-4957730, Email: aalesina@harvard.edu)

\section{Recommended Citation}

Alesina, A., Ardagna, S., \& Galasso, V. (2010). The Euro and Structural Reforms. Review of Economics and Institutions, 2(1), Article 2. doi: 10.5202/rei.v2i1.2.

Retrieved from http://www.rei.unipg.it/rei/article/view/24 
area had a better policy performance after adopting the common currency?

High inflation countries have gained a sound monetary policy with the adoption of the common currency and the European Central Bank. The Euro does not have any direct implication for fiscal policy, ${ }^{1}$ but its adoption was accompanied first by the imposition of converge criteria on budget deficits and public debt and then by the Stability and Growth Pact (SGP), which established some rules about deficits. For some high-debt countries (e.g., Italy, Belgium, and Greece), the threat of being left out served as an incentive to initiate fiscal adjustments. However, once the Euro was introduced, the threat of exclusion vanished, ${ }^{2}$ large deficits reappeared in several member countries, and the SGP was widely violated: a recent paper by Fatas and Mihov (2010) discusses fiscal policy in the Euro area. We focus here on structural reforms.

Why should joining the common monetary area accelerate and facilitate structural reforms? We can think of a few sound economic arguments and some wishful thinking. On the former (and more solid) ground, more competition due to the single market might increase the cost of regulation in the product markets. The protection of insider firms and workers would become more costly and more visible to consumers and voters. For example, imagine a country that protects a national airline at the expense of a low-cost one that flies in the rest of the Union: the costs for the travellers and taxpayers would be large and obvious. This would also weaken the insiders of the protected national airline, from union workers to pilots to managers accumulating losses at the expenses of taxpayers. Of course, this argument presupposes that the Euro per se is a necessary condition for having a truly common market, a point which requires discussion. Second, the elimination of strategic devaluations shuts down a (possibly temporary) adjustment channel for a country losing competitiveness. In the product market, this means that firms and their organizations may demand deregulation of the market for inputs such as non-tradable services, energy, and transportation to contain costs. Also, if real wage growth is out of line with productivity, a nominal devaluation is not available any more as a solution (or a palliative). This creates incentives for countries to free their labor markets from regulations that create obstacles for real wage adjustments and labor mobility and flexibility. In fact, those who were skeptical about the introduction of the Euro (see Obstfeld 1997, for instance) raised precisely the issue of real wage adjustment and labor market rigidities: the elimination of those was

\footnotetext{
${ }^{1}$ One possible indirect channel is through an interest rate effect caused by very large public debt of some (large) countries, but this effect is likely to be small.

${ }^{2}$ See Eichengreen (2010) on the low probability of a collapse of the Euro system.
} 
seen as a condition difficult to implement but necessary for the Euro to survive. It is interesting to note that the pre-Euro economic debate focused much more on labor market reforms and much less, or not at all, on product markets, while in reality, as we will see below, the latter markets were liberalized first.

The wishful thinking part was the rhetoric, often too common in Europe, according to which any step towards integration is "by definition" good and brings about all sort of wonderful achievements for the Continent. More seriously, many commentators viewed the adoption of the Euro as essentially a political move, a step towards some sort of United States of Europe. Jacques Delors is quoted as saying:

«Obsession about budgetary constraints means that the people forget too often about the political objectives of the European constitution. The argument in favor of the single currency should be based on the desire to live together in peace». ${ }^{3}$

When we started this research project, we were rather skeptical that we would find any effect of the Euro on structural reforms. English-speaking countries like the US, New Zealand, the UK, and Ireland had started major deregulation processes well before the birth of the Euro, some Nordic countries (in and out of the Euro area) had followed more recently as a result of poor economic performance in the nineties, and some laggards like Greece, Belgium, Italy, France and Germany were struggling to keep the pace. The Euro did not seem to have much to do with this timing. Much to our surprise, the empirical results were different. We uncovered significant correlations between the speed of adoption of structural reforms in the goods market and the adoption of the Euro. With respect to labor markets, the picture is more nuanced and complex. We find no evidence that the adoption of the Euro has accelerated labor market reforms in the "primary" market. This result does not imply that NO labor market reforms have occurred in Europe, but rather means that the adoption of the Euro has not accelerated reforms. However, in several countries in Europe, we now have a "secondary" market of labor with temporary and much more flexible contracts (see Bertola, 2008, for an assessment of the role of the EURO on labor market outcomes). We still do not have good data on a comparable international basis to examine the evolution of the markets. Indirectly, however, one could look at whether nominal wages have reacted more or less to past inflation and whether there has been wage moderation and, therefore, a smaller "second round" inflationary effect. We find that, in countries preparing to enter the Euro during the period from 1993 to 1998, there have indeed been signs of substantial wage moderation and a slowing down of the adjustment of

${ }^{3}$ See Eichengreen (2010) for the original citation. See Alesina and Perotti (2004) for a criticism of EU rhetoric. 
nominal wages to past inflation. This is likely to have been part of the macroeconomic efforts to meet the criteria to enter the monetary union. After the adoption of the Euro, wage moderation seems to have lost some steam, perhaps as a result of "fatigue". However, in certain countries such as Germany, wage moderation continued until recently. In others, like Italy and France, the evidence is mixed.

We also investigated the sequencing of goods and labor market reforms. The former have generally come sooner than the latter. This important issue has been raised by Blanchard and Giavazzi (2003) and empirically investigated by Fiori et al. (2007). Our results show that deregulation of labor markets is made easier by product market deregulation. However, there are features of the labor market which seem to be a useful precondition for product market deregulation: namely, the reduction of firing costs and, even more, the existence of unemployment benefits. This makes sense, since deregulation of product markets implies labor reallocations across firms and sectors, which require some labor market flexibility, any may lead, at least in the short run, to higher unemployment.

We should be clear from the start that we are considering a handful of countries: eleven original members of the Euro area (all but Luxemburg), a few EU but not Euro members and the remaining OECD countries. We are also looking at a one-shot event: the introduction of the Euro. It is possible that a certain timing of reforms across countries may lead to a spurious correlation that happens to coincide with the adoption of the Euro. ${ }^{4}$ Or it may be possible that it is not the Euro per se but the membership in the European Union that creates incentives for product market deregulation and there are simply not enough countries that are members of the EU but not members of the monetary union to identify this difference.

Finally, the decision to adopt the Euro is clearly not exogenous, and we try to address issues of endogeneity. The recent literature on currency areas (Alesina and Barro, 2002; Alesina et al., 2002) offers insight about instruments that may have led to the decision of adoption. One should, however, be aware that various countries adopted the Euro for different reasons. In some cases, it was done mostly for anchoring purposes (e.g., in Italy), while in other cases, the intention was to be at the core of the European integration process (e.g., in France and Germany). In fact, one theme of the pre-Euro debate amongst economists was: "What is the benefit for Germany?". There seemed to be no big economic gains for this

\footnotetext{
${ }^{4}$ For instance some directive of the European Commission regarding some sectors decided in the mid nineties implied actions to be taken in 1998 and 2000 for all members of the European Union. This timing coincide with the adoption of the Euro. Note, however, that these directives do not apply only to EMU countries but to all the EU countries. Nevertheless this timing may imply some spurious correlation.
} 
country, which seemed to provide the service of being an anti-inflation anchor without receiving an obvious benefit in return. However, the benefit was political. To put it differently, the decision was partly dictated by non-economic factors hard to capture with an instrument.

We are not the first to investigate the relationship between the adoption of the Euro and structural reforms. IMF (2004) suggests that belonging to the EU accelerates the reform process in the product market but has no conclusive effect on the labor market. Yet this paper fails to disentangle the effects of the adoption of the Euro and of the European Single Market (ESM). Hoj et al. (2006) provide supporting evidence to these results. They find a positive effect of the ESM on product market reforms - particularly in the transportation and telecommunication sectors - but no impact on the labor market. However, they do not directly test for the effects of the Euro. Duval and Elmeskov (2005) instead investigate this issue using a database of OECD countries, in which they analyze large structural reforms in the labor and product market. Stacking together these (different) reform measures, they conclude that a lack of monetary autonomy, which is defined as belonging to the EMU or to other fixed exchange rate regimes, ${ }^{5}$ can have a negative, significant impact of the probability of undertaking large structural reforms, but only in large economies. In a database of 178 countries on a longer, yet less recent, time span (1970-2000), Belke et al. (2005) obtain different results. They find that a higher degree of monetary authority independence, as measured by an index of exchange rate flexibility, has a positive impact on an overall index of reform effort, especially in the financial and banking sectors. They find no robust evidence for an index of market regulation in the sample of OECD countries.

This paper is organized as follows: in section 2 , we discuss the rationale for which the Euro might favor structural reforms. Section 3 presents our results on product market deregulation. Section 4 discusses results on labor market reforms, while the last section contains the conclusion.

\section{Structural Reforms and the Euro}

\subsection{Why Should the Euro Matter?}

The adoption of the Euro and the implementation of structural reforms in the labor and product markets seem, at first glance, to be two largely unrelated events. However, the Euro has always been portrayed as the final stage of a process of economic integration among the country

${ }^{5}$ For instance, Austria is classified under a de facto fixed exchange regime with the Deutsche Mark, even before the EMU. 
members of the European Union that involved more trade, more labor and capital mobility: in a word, fewer restrictions on the mobility of goods, services and people. To achieve this goal, the introduction of the European Single Market (the ESM) in 1992 established a legal framework to increase trade and competition in the EU and allowed the European Commission to rule against state aid or against monopolistic practices to all EU members. Thus, it seems quite plausible that the ESM would have had an effect on product and labor market reform. But the subsequent adoption of the Euro did not have direct legal effects on competition policies. Did it have economic implications on it?

Several commentators have discussed various reasons why the adoption of the Euro may facilitate or, on the contrary, create obstacles to the adoption of structural reforms.

On the pro-reform side, one may argue that entrance into the EMU acts as an external constraint that pushes countries to reform. By relinquishing the control of the monetary policy to an external authority (the European Central Bank - ECB), member countries become unable to use their monetary policy to accommodate negative shocks. This might have created incentives to liberalize the labor and product market in order to rely more heavily on market-based adjustments that take place through changes in prices and wages (Bean, 1998 and Duval and Elmeskov, 2005).

A single currency may also increase price transparency and therefore facilitate trade. A larger European market increases competition and makes it more difficult for domestic monopolists to protect their rents. It is certainly true that Europe does not have a truly common market in every sector, especially in the service sector, where domestic protection, direct or indirect, is still widespread. Yet, the degree of competition and integration in the European product market has largely increased in the last two decades. To the extent that a larger common market makes it more difficult for local monopolists to dominate local markets, this might have created pressures to deregulate product markets. Yet, is this the result of the Euro increasing the trading opportunities across member countries, or is it simply the impact of the ESM? In the empirical analysis, we try to disentangle these two effects.

The question of whether a monetary union is necessary for a common market and whether it reduces trade barriers across countries and facilitates commerce in goods, services and financial assets has recently received much attention following a provocative paper by Rose (2000). This paper found that monetary unions have an extremely large effect on trade amongst members. Critics argued (amongst other things) that most monetary unions in Rose's sample involved very small countries and that the effects would have been much smaller in the Euro area, an issue which 
the recent paper by Frankel (2010) tackles. ${ }^{6}$ According to him, the adoption of the Euro appears to have facilitated trade among member countries, even though the order of magnitude of this effect is on a different scale relative to Rose (2000) and seems more realistic. Research applied to Canada and the US showed that trade between Canadian provinces, even ones that were thousands of miles apart, was easier than trade between US states and bordering Canadian provinces, suggesting that a single currency matters for trade. ${ }^{7}$

Note that these pro-reform arguments based on the role of trade imply that most action should take place in the tradable sector, where competition becomes stronger, rather than in the non-tradable service sector. But firms in the tradable sector may react to an increase in competition by translating this pressure upstream onto the intermediate goods producers - and hence only on the service sector - and onto the labor market (see Nicoletti and Scarpetta, 2005).

The economic literature also provides some arguments suggesting that the Euro may hinder structural reforms. Saint-Paul and Bentolila (2000) argue that, under the ESM, the up-front cost of structural reforms may increase. Some labor market reforms may have positive long-term effects but entail a negative short-term impact in terms of higher unemployment. For this reason, several commentators have favored a two-handed approach: structural reform on the supply side, accompanied by expansionary aggregate demand policies. Under the Euro, this twohanded policy may be more difficult because aggregate demand is more constrained at the national level and monetary policy is in the hands of the ECB. A similar argument may apply to pension reforms. They may provide long-term savings for the social security funds but may also imply short-term budget deficits, which may violate the limits imposed by the Growth and Stability Pact.

Obstfeld (1997), in his early and wide-ranging review of the pros and cons of the Euro, emphasized that the Euro would eliminate a major channel of adjustment to macroeconomic shocks, namely a nominal devaluation of the exchange rate, to regain competitiveness by reducing real wages for given (rigid) nominal wages. He suggested that this might put pressure on the unions to be more flexible about allowing adjustments to nominal and real wages and argued that this was a necessary condition for the Euro to survive. The pessimists argued that unions would not be so flexible in Europe and that, on the contrary, they would fuel political momentum against the Euro project, leading to its collapse.

\footnotetext{
${ }^{6}$ Alesina and Barro (2002), Alesina at al. (2002), Persson (2001), Thom and Welsh (2002), and Tenreyro (2007) address theoretically and empirically a host of issues relating the effect of monetary unions on trade.

${ }^{7}$ See, for instance, McCallum (1995).
} 
Reality turned out to be more creative than economists' predictions. There have certainly been complaints and political rumblings against the Euro, mainly in countries which felt they were especially in need of devaluation, as documented by Eichengreen (2010), but the Euro has not collapsed and does not seem even close to doing so. Sure enough, the political "battle" with the unions for labor market reforms in many countries is still in place, and the next few years may be critical.

Since, in many European countries, the labor unions have effectively become unions of old workers, public employees and pensioners (in Italy, for instance, the majority of union members are retired), it should not come as a surprise that they tolerated or even endorsed the introduction of temporary job contracts in which young, entry-level workers would be hired without much or any protection at low wages and could be fired at will by the employers. In exchange, they kept a very high degree of protection for older workers in the traditional labor markets. Spain, Italy and France are prime examples. ${ }^{8}$ In Italy, around a third of the newly created jobs are temporary contracts, and in Spain, the percentage reaches $50 \%$. In the short run, this has worked in terms of increasing employment. In the last ten years in Europe, about 18 million jobs have been created, just as many as in the US. But in the medium run, lacking further reforms, this situation may become explosive, because such a two-tier market might be unsustainable.

One may argue that, as these temporary workers became a large minority of the workforce, they will put pressure on the workers in the traditional sector to abandon some of their privileges, creating a momentum in favor of deregulation of the entire labor market. ${ }^{9}$ However, there is another possibility. These temporary workers may demand to enter the traditional labor market with all its implied protection and rules against firing. If all these workers are simply shifted into the traditionally rigid labor market of union-protected elderly workers, Europe will move back ten years. In summary, labor markets in several European countries are then in a precarious position: half-baked reforms have created a twotier labor market that is economically inefficient and politically unsustainable.

Finally, this discussion relates to issues of sequencing of reform, i.e., is it more politically feasible to move first with product market deregulation or labor market deregulation? Blanchard and Giavazzi (2003) argued that European countries should first deregulate the product market, claiming this would make labor market reforms easier. The reasoning is that

\footnotetext{
${ }^{8}$ See Saint-Paul (1996) (2000) for an early discussion of reforms that avoid touching the interests on incumbents workers and focus only on new entrants and also for a comparison of French and Spanish early reform attempts.

${ }^{9}$ See Saint-Paul (1999) for a formalization of this argument.
} 
product market regulation creates rents which are enjoyed both by incumbent firms and by labor unions. Unions would strenuously oppose labor market reforms that reduce their rents. Product market reforms would curtail rents, reducing the benefits for the unions from the status quo in the labor market and thus reducing their opposition to labor market reforms.

The argument is compelling, and as we will see below, European countries have indeed moved faster on product market liberalizations than on labor market ones. There is, however, one important caveat. Deregulation of product markets sometimes implies closures or reductions in size of incumbent firms in favor of new entrants and, more generally, reallocation of labor force from firm to firm and sector to sector. This process of "creative destruction" generates temporary unemployment. In countries in which firing is costly, if not virtually impossible, this process is difficult. In this respect, the elimination or reduction of firing costs is then a prerequisite for product market liberalization to work. The elimination of firing costs requires some well-designed system of unemployment compensation, but not all European countries have this, a case in point being Italy. Inefficiencies in the system of unemployment compensation give the unions ammunition to defend existing jobs and oppose restructuring. So in this respect, a labor market reform that reduces firing costs and introduces unemployment compensation systems seems like a prerequisite for a well-functioning product market deregulation. Denmark is an example of a country in which labor market reforms have moved exactly in this direction. ${ }^{10}$

\subsection{When do Reforms Occur?}

In addition to the adoption of the Euro, other factors may create incentives for governments to adopt structural reforms. On the one hand, one needs to take such factors into account as controls, and they are interesting in their own right. One commonly held view is that governments reform when they are in a crisis and they have their backs against the wall. For the case of fiscal reforms, one can easily identify a "crisis" as a runaway deficit, and in fact, Alesina et al. (2006) show evidence consistent with this hypothesis. Using a large sample of OECD and developing countries, they show that fiscal adjustments and stabilization of inflation are more likely to occur when this kind of macroeconomic imbalance degenerates into a crisis of runaway (hyper)

\footnotetext{
${ }^{10}$ See for instance Alesina and Giavazzi (2006) for some discussion of the Danish case and the applicability to other European countries.
} 
inflation or of very high budget deficits. ${ }^{11}$ The case of structural reforms is more complicated. Lack of reforms may lead to a slow decline which does not degenerate into a sudden crisis. However, when the decline, evaluated in terms of prolonged periods of low growth, begins to become "front page news", then reform blockers may lose some of their political clout. Recent discussions of relative decline in Europe (and particularly of Italy) may be leading in that direction. ${ }^{12}$ However, the recent financial crisis may have generated a political movement in some countries against deregulation and in favor of a return to easy and long-term state intervention. At the time of this writing, it is hard to predict how much the tides will move towards re-regulation.

Much has also been written about the political cycle and reforms. ${ }^{13}$ Conventional wisdom suggests that governments should not introduce reforms close to elections and that, in general, liberalizing and/or fiscally conservative reforms lead to electoral losses. Thus, if a government has a chance of introducing reforms, it ought to do so soon after it is appointed for two possible reasons: first, to take advantage of the honeymoon period, and second, because the short-term costs of reforms will be gone before the next election. We examine the timing of reforms in relation to the electoral cycle, and we do find some evidence that reforms tend to occur at the beginning of a new term. As for the likelihood that the reforming government will lose the next election, one has to maintain a healthy dose of skepticism with regard to "conventional wisdom." For instance, Alesina et al. (1998) show that governments that engaged in sharp fiscal adjustments have often been reappointed.

\section{Product Markets: the Evidence}

\subsection{The Data on Regulation}

We use yearly data on 21 OECD countries (Australia, Austria, Belgium, Canada, Switzerland, Germany, Denmark, Spain, Finland, France, the UK, Greece, Ireland, Italy, Japan, the Netherlands, New Zealand, Norway, Portugal, Sweden, and the US) covering a maximum time span from 1975 to 2003. The data come from a variety of different sources. In the next sections, we describe the regulatory, macroeconomic and political data;

\footnotetext{
${ }^{11}$ See Alesina and Drazen (1991) and Drazen and Grilli (1993) for models consistent with this hypothesis and Drazen and Easterly (2001) for empirical evidence. See also Drazen (2000) for an extensive discussion of the political economy of stabilization policies.

${ }^{12}$ See Alesina and Giavazzi (2006) for a recent discussion of potential European decline due to insufficient reforms.

${ }^{13}$ See Alesina et al. (1997) for work on the political business cycles and Brender and Drazen (2005) for a political budget cycle model.
} 
the Appendix includes the exact definition and source of each variable we use in the empirical analysis.

We use time-varying measures of regulation for seven nonmanufacturing industries in 21 OECD countries for the period 1975-2003. The data have been collected by Conway and Nicoletti (2007) from both national sources (by means of specific surveys) and published sources and are described in detail by Nicoletti and Scarpetta (2003). The regulatory indicators measure, on a scale from 0 to 6 (from least to most restrictive), restrictions on competition and private governance in the following industries: electricity and gas supply, road freight, air passenger transport, rail transport, post and telecommunications (fixed and mobile).

The summary index of regulation includes information on entry barriers, public ownership, the market share of the dominant player(s) (in the telephone, gas and railroad sectors), and price controls (in the road freight industry). Entry barriers cover legal limitations on the number of companies in potentially competitive markets and rules on vertical integration of network industries. The barriers to entry indicator takes a value of 0 when entry is free (i.e., a situation with three or more competitors and with complete ownership separation of natural monopoly and competitive segments of the industry) and a value of 6 when entry is severely restricted (i.e., situations with legal monopoly and full vertical integration in network industries or restrictive licensing in other industries). Intermediate values represent partial liberalization of entry (e.g., legal duopoly, mere accounting separation of natural monopoly and competitive segments). Public ownership measures the share of equity owned by central or municipal governments in firms of a given sector. The two polar cases are no public ownership (a value of 0 for the indicator) and full public ownership (a value of 6 for the indicator). Whenever data are available (i.e., telecoms, air transport), intermediate values of the public ownership indicator are calculated as an increasing function of the actual share of equity held by the government in the dominant firm. In some cases (e.g., the energy industries), a simpler scale is used, pointing to full or majority control by the government (a value of 6), various degrees of mixed public/private ownership (intermediate values), and marginal public share or full private ownership (a value of 0 ).

The construction of the indicators by the OECD involved the following steps: first, they separated indicators for barriers to entry, public ownership, and market share of new entrants, and price controls were created at the finest available level of industry disaggregation (e.g., mobile and fixed telephony). Second, they aggregated indicators at the industry level, taking simple averages or revenue weighted averages (when aggregating horizontal segments of industries, such as mobile and fixed telephony). Third, they computed the index of overall regulation by 
averaging, in each of the seven industries, the indicators of barriers to entry, public ownership, market share of new entrants, and price controls.

Here, we used simple averaging of the indices to reach the level of industry aggregation for which macroeconomic data (value added, labor costs, and employment) are available. More specifically, we have aggregated the regulation indices for the seven sectors in three broader sectors: energy (electricity and gas), communication (telecommunications and post), and transportation (airlines, road freight and railways).

In our benchmark regressions, we use the regulatory indicator REG, which includes all dimensions except public ownership. In the sensitivity analysis, we also consider three other indicators of regulation: the overall indicator including all the regulation dimensions; one indicator which summarizes barriers to entry (comprising legal restrictions and vertical integration); and one indicator which includes only public ownership information. In the augmented regressions, we introduced two additional sectors: retail and professionals. Data on regulation in these two sectors in 21 OECD countries are available only for two years: 1996 (for professionals) or 1998 (for retail) and 2003. These regulatory indicators range from 0 to 6 (from least to most restrictive). In the retail sector, they capture three components: barrier to entry, operational restrictions and price control. For the professionals, indicators measure entry regulations and conduct regulations in four sectors: accounting, architect, engineer and legal services. For a detailed description, see Conway and Nicoletti (2007).

\subsection{The Macroeconomic and Political Data}

The economic data on value added, labor costs, and total employment at the country-sector-year level for the period 1975-2003 come from the OECD STAN database for Industrial Analysis, Revision 3 (ISIC Rev. 3). This database covers both services and manufacturing sectors for the OECD countries. The macroeconomic data for the non-manufacturing sectors for which we have indices of regulation are available at the following level of industry aggregation: (i) electricity, gas and water, (ii) communications and posts, and (iii) transport and storage. From now on, we will name the sectors defined in (i), (ii), and (iii) energy, communications, and transport, respectively. We merge the data from STAN data set with the database containing the regulation indices. As mentioned above, because data on value added, labor costs, and total employment are not available for each single industry for which regulation indices exist, we mapped the industry-level regulatory indicators into the non-manufacturing aggregates covered by the STAN database. Macroeconomic data at the country-year level are from the OECD Economic Outlook n. 80 database. Finally, the Database of Political 
Institutions (DPI) of the World Bank, compiled by Beck, Clarke, Groff, Keefer, and Walsh (2001) and updated in 2004, contains all the political variables employed in the analysis.

\subsection{Patterns of product market deregulation}

Starting in the late seventies, OECD countries have initiated a broadbased process of deregulation. They were not all starting from the same initial position, however. Generally speaking, Anglo-Saxon countries (the US in particular) were less regulated than continental European countries, and they started to deregulate early: the US and the UK in the early eighties, New Zealand in the late seventies, Ireland in the late eighties. In the last two decades, there has been convergence: the difference in the degree of regulation of product markets (at least for the sector for which we have data) is lower now than it was in the early eighties. The laggards are catching on.

In what follows, we divide the countries into three groups: 1) those that adopted the Euro (the EMU group): these countries are Austria, Belgium, Finland, France, Germany, Ireland, Italy, the Netherlands, Portugal, and Spain; 2) those which are part of the European Union but did not adopt the Euro (we called them the European Single Market Group or ESM): these countries are Denmark, Sweden, and the UK; and 3) those which are not in the EU and obviously do not have the Euro: these are Australia, Canada, Japan, New Zealand, Norway, Switzerland, and the US.

Figure 1 shows that all sectors have deregulated, communication more than any other and energy less than any other.

Figure 1 - Deregulation by Sector

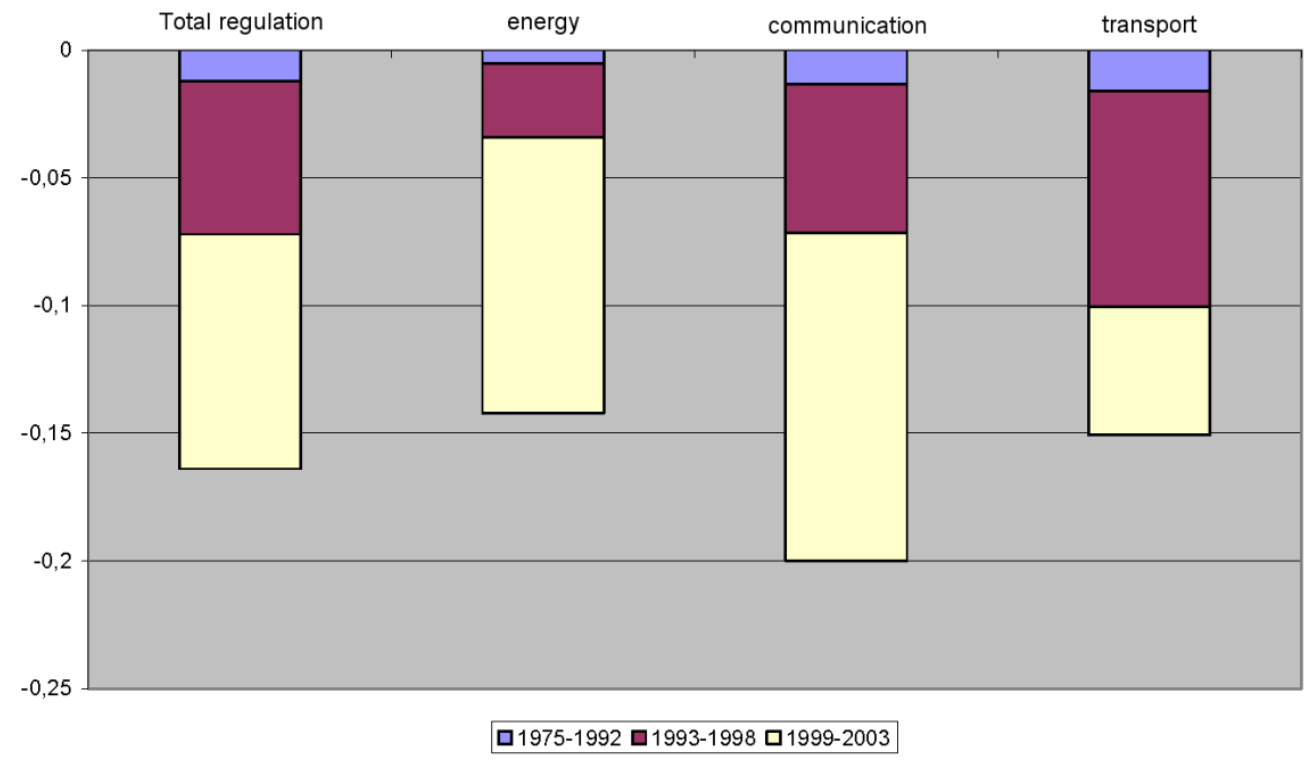


Figure 2 shows that non-EU countries have deregulated less, but, as we said before, they were starting from a much lower average level of regulation.

Figure 2 - Product Market Deregulation

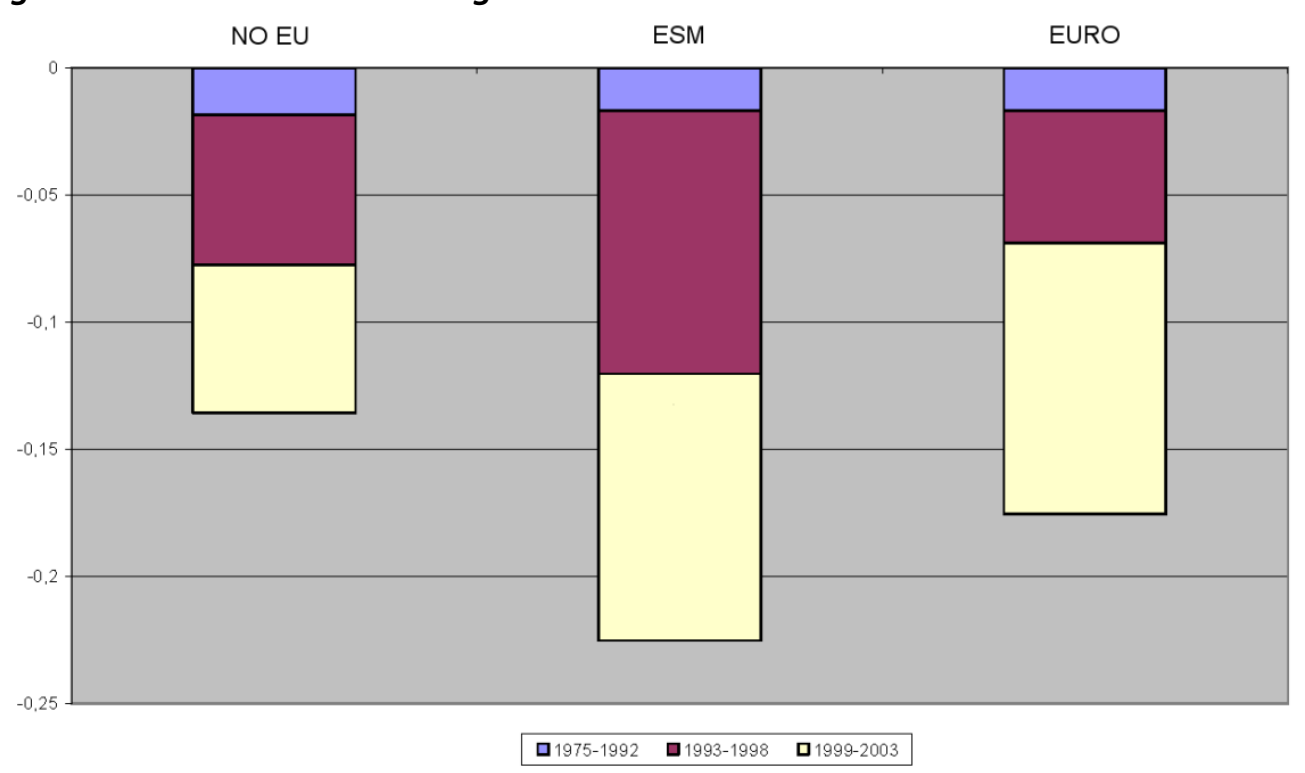

Figure 3 - Convergence in Regulation

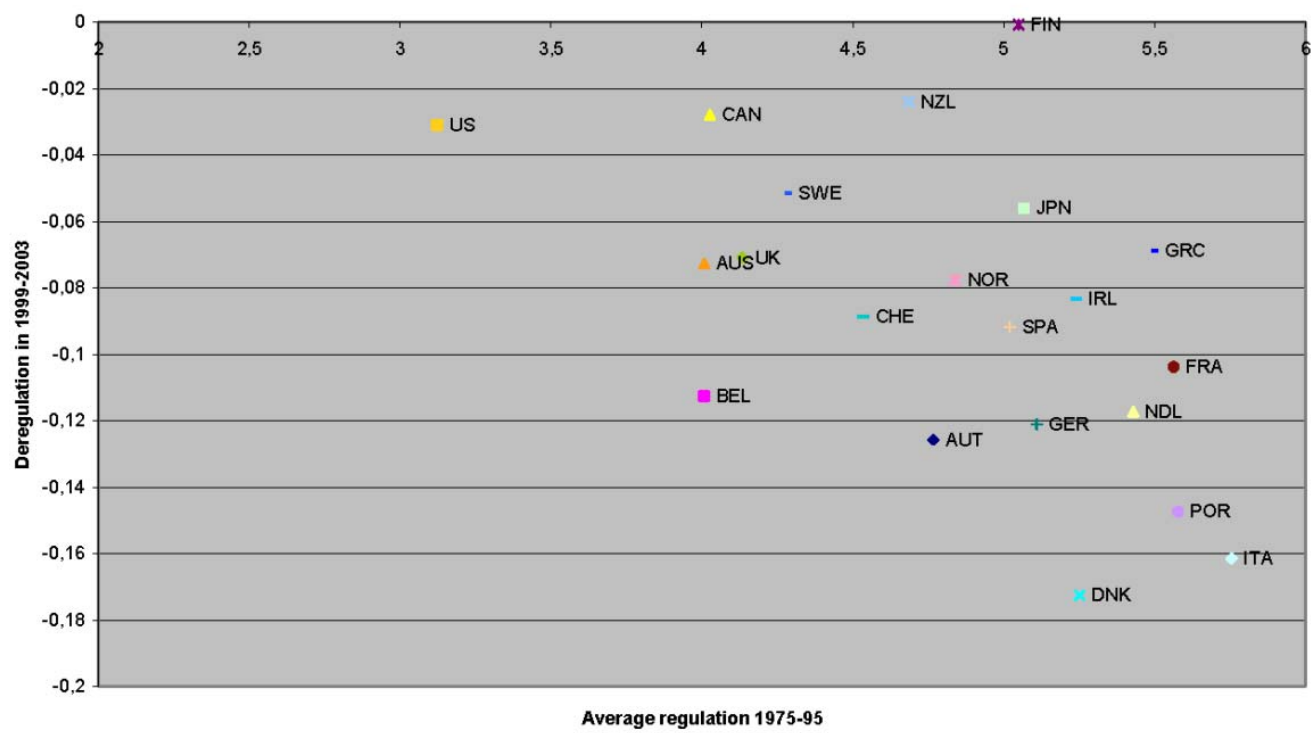

The Single Market group has deregulated most, but in the period 19992003, the EU countries have picked up momentum, having done very little until then, especially given their high initial level of regulation. With the exception of Ireland, very few EU countries did much in terms of deregulation in the eighties, so leaving Ireland out, the pattern for the EU 
countries would be even more skewed towards the recent period. The EMS group includes the UK, which started deregulation early, like other English speaking countries, and also Nordic countries, which have deregulated quite a lot, and this shows in these pictures. Figure 3 shows some pattern of convergence in the deregulation process: since 1999, the countries which deregulated more were clearly those which had higher degrees of regulation until the mid-nineties.

\subsection{The Euro and Product Markets Reforms - Benchmark Specifications}

All our regressions in this section and in the tables discussed in the next sections are estimated with Generalized Least Squares allowing for heteroschedasticity of the error term; they include the lagged value of the left-hand side variable and country, sector and time dummies. Sensitivity analysis confirms that all the results are robust to controlling for country sector-specific dummies, time trends, and country-specific time trends.

In Table 1, we estimate our basic specification of the level of regulation (measured by the indicator variable $R E G$ ). The first three columns include data on the three sectors of transportation, energy, and communications; columns 4-6 also include the two additional sectors: retail and professionals. We measure the impact of the single market program and of the euro on regulation with the dummy variables ESM and EMU. Specifically, ESM is an indicator variable equal to 1 from 1993 onwards for all countries that belong to the European Union (i.e., Austria, Belgium, Denmark, Germany, Finland, France, Greece, Ireland, Italy, the Netherlands, Portugal, Spain, Sweden, and the UK) and equal to 0 otherwise. EMU is an indicator variable equal to 1 from 1999 onward only for those countries of the European Union that have adopted the euro (i.e., Austria, Belgium, Germany, Finland, France, Greece, Ireland, Italy, the Netherlands, Portugal, and Spain) and equal to zero otherwise.

In Column 1 shows that both the single market and the euro have accelerated deregulation: the coefficients of ESM and EMU are negative (equal to -0.064 and -0.18 respectively) and statistically significant at the $5 \%$ level or better. Interestingly, the adoption of the Euro has had a larger (about three times as large) impact on regulation than that of the single market program, and for a country that participated in the single market and adopted the Euro, our estimates imply that the level of regulation decreased by about -0.25 points.

In column 2, we check whether these results hold for each sector in our sample. The adoption of the Euro was especially important for energy and communications, while the single market was key for transportation and 
had no statistically significant effect in the energy and communication sectors. ${ }^{14}$

Table 1 - The Euro and Product Markets Reforms

\begin{tabular}{|c|c|c|c|c|c|c|}
\hline & \multicolumn{3}{|c|}{3 SECTORS } & \multicolumn{3}{|c|}{5 SECTORS } \\
\hline & $\begin{array}{c}\text { (1) } \\
\text { REG }\end{array}$ & $\begin{array}{c}\text { (2) } \\
\text { REG }\end{array}$ & $\begin{array}{c}\text { (3) } \\
\text { REG }\end{array}$ & $\begin{array}{l}\text { (4) } \\
\text { REG }\end{array}$ & $\begin{array}{c}\text { (5) } \\
\text { REG }\end{array}$ & $\begin{array}{c}\text { (6) } \\
\text { REG }\end{array}$ \\
\hline $\operatorname{REG}(-1)$ & $\begin{array}{c}0.94 \\
(109.60)^{* * *}\end{array}$ & $\begin{array}{c}0.93 \\
(107.19)^{* *}\end{array}$ & $\begin{array}{c}0.95 \\
(104.66)^{* *}\end{array}$ & $\begin{array}{c}0.93 \\
(112.17)^{* *}\end{array}$ & $\begin{array}{c}0.93 \\
(108.13)^{* * *}\end{array}$ & $\begin{array}{c}0.95 \\
(104.96)^{*}\end{array}$ \\
\hline ESM & $\begin{array}{c}-0.06 \\
(-2.28) * *\end{array}$ & --- & --- & $\begin{array}{c}-0.06 \\
(-2.05)^{* *}\end{array}$ & --- & --- \\
\hline EMU & $\begin{array}{c}-0.18 \\
(-5.28)^{* *}\end{array}$ & --- & --- & $\begin{array}{c}-0.15 \\
(-4.83)^{* *}\end{array}$ & --- & --- \\
\hline ESM*ENERGY & --- & $\begin{array}{c}0.02 \\
(0.61)\end{array}$ & $\begin{array}{c}0.01 \\
(0.23)\end{array}$ & -- & $\begin{array}{c}0.03 \\
(0.70)\end{array}$ & $\begin{array}{c}0.01 \\
(0.24)\end{array}$ \\
\hline ESM*COMMUNICATION & --- & $\begin{array}{l}-0.03 \\
(-0.81)\end{array}$ & $\begin{array}{l}-0.03 \\
(-0.81)\end{array}$ & --- & $\begin{array}{l}-0.03 \\
(-0.72)\end{array}$ & $\begin{array}{c}-0.03 \\
(-0.74)\end{array}$ \\
\hline ESM*TRANSPORT & --- & $\begin{array}{c}-0.16 \\
(-4.35)^{* * *}\end{array}$ & $\begin{array}{c}-0.15 \\
(-4.05)^{* * *}\end{array}$ & --- & $\begin{array}{c}-0.16 \\
(-4.32)^{* *}\end{array}$ & $\begin{array}{c}-0.15 \\
(-4.02)^{* *}\end{array}$ \\
\hline ESM*RETAIL & --- & --- & --- & --- & $\begin{array}{c}-0.26 \\
(-2.07)^{* *}\end{array}$ & $\begin{array}{c}-0.27 \\
(-2.54)^{* *}\end{array}$ \\
\hline ESM*PROFESSIONAL & --- & --- & --- & --- & $\begin{array}{c}0.22 \\
(2.74)^{* *}\end{array}$ & $\begin{array}{c}0.24 \\
(2.87)^{* *}\end{array}$ \\
\hline EMU*ENERGY & --- & $\begin{array}{c}-0.43 \\
(-9.07)^{* * *}\end{array}$ & $\begin{array}{c}0.04 \\
(0.49)\end{array}$ & --- & $\begin{array}{c}-0.43 \\
(-8.95)^{* *}\end{array}$ & $\begin{array}{c}0.11 \\
(1.23)\end{array}$ \\
\hline EMU*COMMUNICATION & --- & $\begin{array}{c}-0.28 \\
(-5.74)^{* *}\end{array}$ & $\begin{array}{c}0.02 \\
(0.31)\end{array}$ & --- & $\begin{array}{c}-0.29 \\
(-5.79)^{* *}\end{array}$ & $\begin{array}{c}0.06 \\
(0.86)\end{array}$ \\
\hline EMU*TRANSPORT & --- & $\begin{array}{c}0.11 \\
(2.39)^{* *}\end{array}$ & $\begin{array}{c}0.46 \\
(6.26)^{* *}\end{array}$ & --- & $\begin{array}{c}0.11 \\
(2.35)^{* *}\end{array}$ & $\begin{array}{c}0.50 \\
(6.98)^{* * *}\end{array}$ \\
\hline EMU*RETAIL & --- & --- & --- & --- & $\begin{array}{c}0.52 \\
(4.16)^{* *}\end{array}$ & $\begin{array}{c}0.85 \\
(5.75)^{* *}\end{array}$ \\
\hline EMU*PROFESSIONAL & --- & --- & --- & --- & $\begin{array}{c}-0.09 \\
(-1.14)\end{array}$ & $\begin{array}{c}0.29 \\
(2.94)^{* *}\end{array}$ \\
\hline EMU*REG(-1) & --- & --- & $\begin{array}{c}-0.12 \\
(-6.24)^{* *}\end{array}$ & --- & --- & $\begin{array}{c}-0.14 \\
(-7.34)^{* *}\end{array}$ \\
\hline OBSERVATIONS & 1764 & 1764 & 1764 & 1802 & 1802 & 1802 \\
\hline
\end{tabular}

Notes: Generalized least squares regressions allowing for heteroschedasticity of the error term and including country, sector and time dummies. T-statisitcs in parenthesis. $* * * * *$, coefficients statistically significant at $1 \%, 5 \%, 10 \%$ level, respectively. REG indicator of regulatory impediments to product market competition, excluding public ownership; ENERGY, COMMUNICATIONS, TRANSPORT, RETAIL and PROFESSIONAL sectorial dummy variable that equals 1 for the corresponding sector; ESM dummy variable equal to 1 from 1993 onward for the countries that enter the EU's Single Market Programme; EMU dummy variable equal to 1 from 1999 onward for the countries that enter the EMU. Columns (1)-(3) include the following 3 sectors: ENERGY, COMMUNICATIONS, TRANSPORT. Columns (4)-(6) include all 5 sectors in our database: ENERGY, COMMUNICATIONS, TRANSPORT, RETAIL and PROFESSIONAL. See also Appendix for the exact definition of the variables.

Finally, we investigate whether the effect of the single market program and the adoption of the Euro depends on the initial level of regulation by

${ }^{14} \mathrm{We}$ also checked whether the countries that deregulated after the adoption of the Euro in the years following 1999 had experienced a "delay" in deregulation because they were "too busy" achieving the target criteria to join the monetary union. More specifically, we tested what happened to EU countries in the run up to the Euro during the period 1993-99. We did not find any evidence of an effect of "postponement." 
adding the variables $E S M^{*} R E G(-1)$ and $E M U^{*} R E G(-1)$ to the specification of column 2. The effect of the single market is independent of the level of regulation: the coefficient of the interaction term between the single market dummy and the level of regulation lagged one is not statistically significant both in a specification in which we exclude the variable $E M U^{*} R E G(-1)$ and in one in which we include it (results are not shown but are available upon request).

On the contrary, column 3 shows that the effect of the Euro was larger the larger the initial level of regulation, reemphasizing the process of convergence mentioned above. Note that, in column 3 , the coefficients of the dummy variable EMU in the energy and communication sectors become positive but insignificant (see column 3). However, the magnitude of the coefficients of the variables EMU*ENERGY, and EMU*COMMUNICATIONS and of EMU*REG(-1) imply that, for each value of $R E G(-1)$ observed in the energy and communications sectors, adopting the Euro is always associated with deregulation.

The last three columns of Table 1 re-estimate the specifications of column 1-3 in the sample in which the two additional sectors, retail and professionals, are also included. The estimates show that the single market, not the Euro, was important for the retail sector and that the professional sectors has not been deregulated at all.

Finally, the regulatory variable that we are using (REG) looks at "all" aspects of regulation except the one of public ownership. Results hold when we use the indicator of regulation that only measures barriers to entry and vertical integration and the more general indicator that also looks at public ownership.

Summarizing, the introduction of the Euro has contributed to structural reforms in the product markets. This effect is above and beyond the effect of membership in the European Union from 1993 onwards. Moreover, deregulation was stronger in EMU country-sectors with higher initial levels of regulation. This may give some prima-facie and indirect support to the idea that deregulation was most needed once countries could not rely on exchange rate devaluations to boost competitiveness. In fact, the more heavily regulated (and less productive and competitive) countrysectors may have been those suffering the most from the loss of competitive devaluations and, hence, the ones that were forced to liberalize the most. In the next section, we investigate this idea in more detail.

\subsection{Why Should the Euro Matter? Empirical Evidence}

One of the reasons why a country joining the EMU may want to adopt structural reforms is that the competitive devaluation channel is not 
available anymore as a tool (or a palliative) to regain competitiveness. ${ }^{15}$ In Table 2, we explore this idea.

Lacking competitiveness indicators at the country-sector-year level for the period 1975-2003 for the energy, communications, and transport sectors, we measure competitiveness with variables varying only along the country-year dimension. We use two different indicators: the growth rate of the CPI relative to competitors at $\mathrm{t}-1$ (COMPET1(-1)) and the growth rate of the export goods deflators relative to competitors at $t-1$ (COMPET2(-1)). We include the linear and quadratic terms to capture for possible non-linearities; we add the interaction term of the competitiveness indicators and the EMU dummy variable to investigate whether the loss of exchange rate devaluation as a policy instrument to boost competitiveness leads to structural reforms. The coefficients of the variables COMPET1(-1) and COMPET2(-1) and their squares are not statistically significant at conventional critical values, suggesting that deregulation reforms do not generally occur in countries that are losing competitiveness.

However, this is not true for countries that adopted the Euro. In fact, the interaction terms of the competitiveness indicators and the EMU dummy variable are negative and statistically significant at the 5\% level, suggesting that, for EMU countries, the higher the growth rate of CPI and export goods deflators relative to competitors at $t-1$, the larger the decrease of the regulatory index.

Finally, in columns 3 and 6, we control for the number of devaluations countries that adopted the Euro experienced in the period 1979-1993. Our idea is that only countries that de facto used the exchange rate as a tool to regain competitiveness should suffer from its loss and liberalize markets. The variable N. OF DEVALUATIONS FROM 1979-1993 is equal to 5 for France, 1 for Belgium, 7 for Italy and 3 for Ireland. It is equal to 0 otherwise. For the EMU countries, the more devaluations a country did from 1979 to 1993, the larger the decrease of the regulatory index (but the coefficient is statistically significant only at the $10 \%$ level).

Two caveats are worth mentioning. First, we are treating our competitiveness indicators as exogenous. While this may clearly not be the case, note that, here, we are not really interested in the effect of competitiveness on regulation but on its differential effect among EMU and other countries.

\footnotetext{
${ }^{15}$ Bugamelli et al. (2010) present some microeconomic evidence suggesting that sectors that have gone through deeper transformations and that enjoyed more productivity gains are exactly those that benefited more from pre-1999 devaluation.
} 
Table 2 - The Euro, Product Markets Reforms, and Competitiveness

\begin{tabular}{|c|c|c|c|c|c|c|}
\hline & & 3 SECTORS & & & 5 SECTORS & \\
\hline & (1) & (2) & (3) & (4) & (5) & (6) \\
\hline $\operatorname{REG}(-1)$ & $\begin{array}{c}0.95 \\
(101.60)^{* *}\end{array}$ & $\begin{array}{c}0.94 \\
(92.94)^{* * *}\end{array}$ & $\begin{array}{c}0.95 \\
(104.17)^{* *}\end{array}$ & $\begin{array}{c}0.95 \\
(101.85)^{* *}\end{array}$ & $\begin{array}{c}0.94 \\
(93.51)^{* * *}\end{array}$ & $\begin{array}{c}0.95 \\
(104.47)^{* * *}\end{array}$ \\
\hline ESM*ENERGY & $\begin{array}{c}0.00 \\
(0.12)\end{array}$ & $\begin{array}{c}0.00 \\
(0.08)\end{array}$ & $\begin{array}{c}0.01 \\
(0.23)\end{array}$ & $\begin{array}{c}0.00 \\
(0.10)\end{array}$ & $\begin{array}{c}0.00 \\
(0.02)\end{array}$ & $\begin{array}{c}0.01 \\
(0.24)\end{array}$ \\
\hline ESM*COMMUNICATION & $\begin{array}{c}-0.03 \\
(-0.84)\end{array}$ & $\begin{array}{c}-0.02 \\
(-0.65)\end{array}$ & $\begin{array}{c}-0.03 \\
(-0.83)\end{array}$ & $\begin{array}{l}-0.03 \\
(-0.75)\end{array}$ & $\begin{array}{l}-0.02 \\
(-0.52)\end{array}$ & $\begin{array}{c}-0.03 \\
(-0.76)\end{array}$ \\
\hline ESM*TRANSPORT & $\begin{array}{c}-0.16 \\
(-4.37)^{*}\end{array}$ & $\begin{array}{c}-0.15 \\
(-3.89)^{* *}\end{array}$ & $\begin{array}{c}-0.15 \\
(-4.05)^{* *}\end{array}$ & $\begin{array}{c}-0.16 \\
(-4.31)^{*}\end{array}$ & $\begin{array}{c}-0.15 \\
(-3.82)^{* *}\end{array}$ & $\begin{array}{c}-0.15 \\
(-4.02)^{*}\end{array}$ \\
\hline ESM*RETAIL & --- & --- & --- & $\begin{array}{c}-0.27 \\
(-2.44)^{* *}\end{array}$ & $\begin{array}{c}-0.26 \\
(-2.18)^{* *}\end{array}$ & $\begin{array}{c}-0.27 \\
(-2.52)^{* *}\end{array}$ \\
\hline ESM*PROFESSIONAL & --- & --- & --- & $\begin{array}{c}0.23 \\
(2.71)^{* * *}\end{array}$ & $\begin{array}{c}0.22 \\
(2.76)^{* * *}\end{array}$ & $\begin{array}{c}0.24 \\
(2.87)^{* *}\end{array}$ \\
\hline EMU*ENERGY & $\begin{array}{c}0.23 \\
(2.38)^{* *}\end{array}$ & $\begin{array}{c}0.20 \\
(1.92)^{*}\end{array}$ & $\begin{array}{c}0.03 \\
(0.30)\end{array}$ & $\begin{array}{c}0.31 \\
(3.42)^{* *}\end{array}$ & $\begin{array}{c}0.28 \\
(3.05)^{* *}\end{array}$ & $\begin{array}{c}0.10 \\
(1.10)\end{array}$ \\
\hline EMU*COMMUNICATION & $\begin{array}{c}0.14 \\
(1.95)^{*}\end{array}$ & $\begin{array}{c}0.12 \\
(1.56)\end{array}$ & $\begin{array}{c}0.02 \\
(0.28)\end{array}$ & $\begin{array}{c}0.19 \\
(2.76)^{* * *}\end{array}$ & $\begin{array}{c}0.17 \\
(2.41)^{* *}\end{array}$ & $\begin{array}{c}0.06 \\
(0.84)\end{array}$ \\
\hline EMU*TRANSPORT & $\begin{array}{c}0.56 \\
(7.37)^{* * *}\end{array}$ & $\begin{array}{c}0.54 \\
(6.66)^{* *}\end{array}$ & $\begin{array}{c}0.44 \\
(6.06)^{* *}\end{array}$ & $\begin{array}{c}0.61 \\
(8.43)^{* * *}\end{array}$ & $\begin{array}{c}0.59 \\
(8.09)^{* *}\end{array}$ & $\begin{array}{c}0.49 \\
(6.84)^{* * *}\end{array}$ \\
\hline EMU*RETAIL & --- & --- & --- & $\begin{array}{c}1.01 \\
(6.73)^{* *}\end{array}$ & $\begin{array}{c}0.95 \\
(5.99)^{* * *}\end{array}$ & $\begin{array}{c}0.85 \\
(5.83)^{* * *}\end{array}$ \\
\hline EMU*PROFESSIONAL & --- & --- & --- & $\begin{array}{c}0.51 \\
(4.91)^{* *}\end{array}$ & $\begin{array}{c}0.46 \\
(5.08)^{* *}\end{array}$ & $\begin{array}{c}0.27 \\
(2.74)^{* * *}\end{array}$ \\
\hline EMU*REG $(-1)$ & $\begin{array}{c}-0.18 \\
(-7.94)^{* *}\end{array}$ & $\begin{array}{c}-0.17 \\
(-7.08)^{* *}\end{array}$ & $\begin{array}{c}-0.11 \\
(-5.51)^{* *}\end{array}$ & $\begin{array}{c}-0.20 \\
(-9.62)^{* *}\end{array}$ & $\begin{array}{c}-0.19 \\
(-9.56)^{* *}\end{array}$ & $\begin{array}{c}-0.13 \\
(-6.79)^{* *}\end{array}$ \\
\hline COMPET1 (-1) & $\begin{array}{c}-0.11 \\
(-0.96)\end{array}$ & --- & --- & $\begin{array}{c}-0.10 \\
(-0.86)\end{array}$ & --- & --- \\
\hline $\operatorname{COMPET}^{2}(-1)$ & $\begin{array}{c}-0.57 \\
(-0.55)\end{array}$ & --- & --- & $\begin{array}{l}-0.56 \\
(-0.53)\end{array}$ & --- & --- \\
\hline EMU*COMPET1 $(-1)$ & $\begin{array}{c}-2.76 \\
(-2.81)^{* *}\end{array}$ & --- & --- & $\begin{array}{c}-2.64 \\
(-2.78)^{* *}\end{array}$ & --- & --- \\
\hline COMPET2 (-1) & --- & $\begin{array}{c}0.05 \\
(0.38)\end{array}$ & --- & --- & $\begin{array}{c}0.05 \\
(0.36)\end{array}$ & --- \\
\hline $\operatorname{COMPET}^{2}(-1)$ & --- & $\begin{array}{l}-0.15 \\
(-0.11)\end{array}$ & --- & --- & $\begin{array}{c}-0.06 \\
(-0.04)\end{array}$ & --- \\
\hline EMU*COMPET2 (-1) & --- & $\begin{array}{c}-1.97 \\
(-2.77)^{* *}\end{array}$ & --- & --- & $\begin{array}{c}-1.96 \\
(-2.78)^{* *}\end{array}$ & --- \\
\hline $\begin{array}{l}\text { N. OF DEVALUATIONS } \\
\text { FROM 1979-1993 }\end{array}$ & --- & --- & $\begin{array}{c}0.02 \\
(3.46)^{* *}\end{array}$ & --- & --- & $\begin{array}{c}-0.01 \\
(-1.89)^{*}\end{array}$ \\
\hline $\begin{array}{l}\text { EMU* N. OF DEVALUATIONS } \\
\text { FROM 1979-1993 }\end{array}$ & --- & --- & $\begin{array}{c}-0.02 \\
(-1.83)^{*}\end{array}$ & --- & --- & $\begin{array}{l}-0.01 \\
(-1.33)\end{array}$ \\
\hline OBSERVATIONS & 1680 & 1572 & 1764 & 1717 & 1609 & 1802 \\
\hline
\end{tabular}

Notes: Generalized least squares regressions allowing for heteroschedasticity of the error term and including country, sector and time dummies. T-statisitcs in parenthesis. $*^{*}, *^{* *}, *$ coefficients statistically significant at $1 \%, 5 \%, 10 \%$ level, respectively. REG indicator of regulatory impediments to product market competition, excluding public ownership; ENERGY, COMMUNICATIONS, TRANSPORT, RETAIL and PROFESSIONAL sectorial dummy variable that equals 1 for the corresponding sector; ESM dummy variable equal to 1 from 1993 onward for the countries that enter the EU's Single Market Programme; EMU dummy variable equal to 1 from 1999 onward for the countries that enter the EMU. COMPET1 growth rate of the CPI relative to competitors; COMPET2 growth rate of the export goods deflators relative to competitors; N. OF DEVALUTIONS FROM 1979-1993: number of devaluations that a country that belonged to the European Monetary System did from 1979 to 1993. See also the Notes to Table 1 and Appendix for the exact definition of the variables. 
Hence, even if the competitiveness indicators were not exogenous, it is not clear why the bias in our estimates should differ among EMU and other countries. Second, the coefficient of the variable EMU*REG(-1) remains negative and statistically significant as in Table 1, suggesting that: (i) our competitiveness indicators are not capturing the loss of competitiveness, and hence the need of reforms, very well when the exchange rate instrument cannot be used anymore; (ii) the Euro is important for structural reforms in product markets for other reasons beyond the fact that the competitive devaluation channel is not available anymore; (iii) what we are identifying as a "Euro effect" is just picking up the impact of some omitted variable; (iv) any combinations of (i), (ii), and/or (iii).

\subsection{Other Determinants of Product Market Reforms}

In this section, we investigate other possible determinants of product market reforms. We also check that accounting for other critical elements that drive reforms does not alter the results we discussed so far on the effect of the Euro on deregulation of product markets.

We begin by testing whether various variables that measure the macroeconomic conditions of each sectors matter. Specifically, in Table 3, we include the sectors' value added, labor expenses and total employment at time $t-1$, measured as a share of country's total value added, labor expenses, and total employment at time $\mathrm{t}-1$.

Blanchard and Giavazzi (2003) suggest that, in the short run, product markets' deregulation reforms generate costs both for incumbent firms and for their workers. Hence, incumbents tend to oppose such reforms. When rents are lower, however, resistance to deregulation falls as the incumbents' short-term losses can be easier outweighed by the future benefits of deregulation.

Results in Table 3 support this argument. In fact, we find that regulation decreases when value added and labor costs of the sector fall, i.e., when the sector's rents decrease. We also find that product markets are deregulated in country-sectors-years with lower employment. Hence, in less labor-intensive sectors, governments can meet less resistance and can more easily implement deregulation measures. In columns 4-6, we also investigate whether there are differential effects between EMU and non-EMU countries relative to the effects of value added, labor costs and employment on regulation, but on this score, we found no differences between EMU and non-EMU countries. 
Table 3 - Other Determinants of Product Markets Reforms (Sectors Indicators)

\begin{tabular}{|c|c|c|c|c|c|c|}
\hline & \multicolumn{3}{|c|}{3 SECTORS } & \multicolumn{3}{|c|}{5 SECTORS } \\
\hline & $\begin{array}{c}\text { (1) } \\
\text { REG }\end{array}$ & $\begin{array}{c}\text { (2) } \\
\text { REG }\end{array}$ & $\begin{array}{l}\text { (3) } \\
\text { REG }\end{array}$ & $\begin{array}{l}\text { (4) } \\
\text { REG }\end{array}$ & $\begin{array}{c}\text { (5) } \\
\text { REG }\end{array}$ & $\begin{array}{l}\text { (6) } \\
\text { REG }\end{array}$ \\
\hline $\operatorname{REG}(-1)$ & $\begin{array}{c}0.94 \\
(84.13)^{* *}\end{array}$ & $\begin{array}{c}0.93 \\
(75.86)^{* *}\end{array}$ & $\begin{array}{c}0.93 \\
(73.56)^{* *}\end{array}$ & $\begin{array}{c}0.94 \\
(84.06)^{* *}\end{array}$ & $\begin{array}{c}0.93 \\
(75.82)^{* *}\end{array}$ & $\begin{array}{c}0.93 \\
(73.43)^{* *}\end{array}$ \\
\hline ESM*ENERGY & $\begin{array}{l}-0.02 \\
(-0.52)\end{array}$ & $\begin{array}{l}-0.02 \\
(-0.59)\end{array}$ & $\begin{array}{l}-0.03 \\
(-0.71)\end{array}$ & $\begin{array}{l}-0.02 \\
(-0.52)\end{array}$ & $\begin{array}{l}-0.03 \\
(-0.66)\end{array}$ & $\begin{array}{l}-0.03 \\
(-0.73)\end{array}$ \\
\hline ESM*COMMUNICATIONS & $\begin{array}{l}-0.05 \\
(-1.36)\end{array}$ & $\begin{array}{c}-0.06 \\
(-1.65)^{*}\end{array}$ & $\begin{array}{c}-0.12 \\
(-2.70)^{* * *}\end{array}$ & $\begin{array}{l}-0.05 \\
(-1.35)\end{array}$ & $\begin{array}{c}-0.06 \\
(-1.66)^{*}\end{array}$ & $\begin{array}{c}-0.12 \\
(-2.76)^{* *}\end{array}$ \\
\hline ESM*TRANSPORT & $\begin{array}{c}-0.18 \\
(4.25)^{* *}\end{array}$ & $\begin{array}{c}-0.18 \\
(-4.02)^{* *}\end{array}$ & $\begin{array}{c}-0.20 \\
(-4.28)^{* *}\end{array}$ & $\begin{array}{c}-0.18 \\
(-4.26)^{* *}\end{array}$ & $\begin{array}{c}-0.18 \\
(-4.07)^{* *}\end{array}$ & $\begin{array}{c}-0.20 \\
(-4.34)^{* *}\end{array}$ \\
\hline EMU*ENERGY & $\begin{array}{c}0.27 \\
(2.48)^{* *}\end{array}$ & $\begin{array}{c}0.19 \\
(1.73)^{*}\end{array}$ & $\begin{array}{c}0.19 \\
(1.65)^{*}\end{array}$ & $\begin{array}{c}0.15 \\
(1.20)\end{array}$ & $\begin{array}{c}0.07 \\
(0.51)\end{array}$ & $\begin{array}{c}0.05 \\
(0.36)\end{array}$ \\
\hline EMU*COMMUNICATIONS & $\begin{array}{c}0.13 \\
(1.68)^{*}\end{array}$ & $\begin{array}{c}0.09 \\
(1.13)\end{array}$ & $\begin{array}{c}0.13 \\
(1.55)\end{array}$ & $\begin{array}{c}0.00 \\
(0.02)\end{array}$ & $\begin{array}{l}-0.04 \\
(-0.30)\end{array}$ & $\begin{array}{l}-0.06 \\
(-0.45)\end{array}$ \\
\hline EMU*TRANSPORT & $\begin{array}{c}0.59 \\
(7.08)^{* *}\end{array}$ & $\begin{array}{c}0.54 \\
(6.40)^{* *}\end{array}$ & $\begin{array}{c}0.54 \\
(5.95)^{* *}\end{array}$ & $\begin{array}{c}0.32 \\
(1.70)^{*}\end{array}$ & $\begin{array}{c}0.28 \\
(0.97)\end{array}$ & $\begin{array}{c}0.05 \\
(0.20)\end{array}$ \\
\hline $\operatorname{EMU*REG~(-1)~}$ & $\begin{array}{c}-0.19 \\
(-7.46)^{* * *}\end{array}$ & $\begin{array}{c}-0.18 \\
(-6.80)^{* *}\end{array}$ & $\begin{array}{c}-0.17 \\
(-6.56)^{* *}\end{array}$ & $\begin{array}{c}-0.19 \\
(-7.50)^{* * *}\end{array}$ & $\begin{array}{c}-0.18 \\
(-6.78)^{* *}\end{array}$ & $\begin{array}{c}-0.17 \\
(-6.25)^{* *}\end{array}$ \\
\hline COMPET1 $(-1)$ & $\begin{array}{l}-0.06 \\
(-0.45)\end{array}$ & $\begin{array}{l}-0.04 \\
(-0.27)\end{array}$ & $\begin{array}{c}0.03 \\
(0.22)\end{array}$ & $\begin{array}{l}-0.06 \\
(-0.47)\end{array}$ & $\begin{array}{c}-0.0 \\
(-0.29) 4\end{array}$ & $\begin{array}{c}0.02 \\
(0.16)\end{array}$ \\
\hline $\operatorname{COMPET}^{2}(-1)$ & $\begin{array}{c}-0.81 \\
(-0.71)\end{array}$ & $\begin{array}{l}-0.85 \\
(-0.71)\end{array}$ & $\begin{array}{l}-0.50 \\
(-0.40)\end{array}$ & $\begin{array}{c}-0.75 \\
(-0.66)\end{array}$ & $\begin{array}{c}-0.77 \\
(-0.64)\end{array}$ & $\begin{array}{c}-0.44 \\
(-0.36)\end{array}$ \\
\hline EMU*COMPET1 (-1) & $\begin{array}{c}-2.63 \\
(-2.19)^{* *}\end{array}$ & $\begin{array}{c}-2.52 \\
(-2.05)^{* *}\end{array}$ & $\begin{array}{c}2.49 \\
(1.93)^{*}\end{array}$ & $\begin{array}{c}-2.79 \\
(-2.31)^{* *}\end{array}$ & $\begin{array}{c}-2.72 \\
(-2.20)^{* *}\end{array}$ & $\begin{array}{c}-2.37 \\
(-1.81)^{*}\end{array}$ \\
\hline VA $(-1)$ & $\begin{array}{c}2.13 \\
(2.24)^{* *}\end{array}$ & $\begin{array}{c}-0.64 \\
(-0.44)\end{array}$ & $\begin{array}{c}-0.42 \\
(-0.29)\end{array}$ & $\begin{array}{c}1.80 \\
(1.86)^{*}\end{array}$ & $\begin{array}{l}-1.33 \\
(-0.88)\end{array}$ & $\begin{array}{l}-0.57 \\
(-0.38)\end{array}$ \\
\hline LABOR EXPENSES (-1) & --- & $\begin{array}{c}3.43 \\
(2.03)^{* *}\end{array}$ & --- & --- & $\begin{array}{c}3.87 \\
(2.24)^{* *}\end{array}$ & --- \\
\hline TOT. EMPLOYMENT (-1) & --- & --- & $\begin{array}{c}4.90 \\
(2.06)^{* *}\end{array}$ & --- & --- & $\begin{array}{c}4.45 \\
(1.85)^{*}\end{array}$ \\
\hline EMU*VALUE ADDED (-1) & --- & --- & --- & $\begin{array}{c}5.57 \\
(1.64)\end{array}$ & $\begin{array}{c}7.03 \\
(1.75)^{*}\end{array}$ & $\begin{array}{c}3.32 \\
(0.75)\end{array}$ \\
\hline EMU*LABOR EXPENSES $(-1)$ & --- & --- & --- & --- & $\begin{array}{l}-1.80 \\
(-0.27)\end{array}$ & \\
\hline EMU*TOT. EMPLOYMENT(-1) & --- & --- & --- & --- & --- & $\begin{array}{c}6.90 \\
(1.08)\end{array}$ \\
\hline OBSERVATIONS & 1383 & 1282 & 1158 & 1383 & 1282 & 1158 \\
\hline $\begin{array}{l}\text { Notes: Generalized least squa } \\
\text { sector and time dummies. T-s } \\
\text { respectively. REG indicator o } \\
\text { ENERGY, COMMUNICATIONS, } \\
\text { corresponding sector; ESM du } \\
\text { Market Programme; EMU dum } \\
\text { growth rate of the CPI rela } \\
\text { competitors; N. OF DEVALUT } \\
\text { European Monetary System di } \\
\text { compensation of employees a }\end{array}$ & $\begin{array}{l}\text { S regressio } \\
\text { tisitcs in pa } \\
\text { regulatory } \\
\text { RANSPORT, } \\
\text { my variabl } \\
\text { y variable } \\
\text { e to comp } \\
\text { NS FROM } \\
\text { from } 1979 \\
\text { the sectoria }\end{array}$ & $\begin{array}{l}\text { llowing for } \\
\text { thesis. **, } \\
\text { ediments } \\
\text { TAlL and P } \\
\text { jual to } 1 \mathrm{fr} \\
\text { al to } 1 \mathrm{from} \\
\text { ors; COMP } \\
\text { 9-1993: n } \\
\text { 993 VA val } \\
\text { vel; TOT Er } \\
\text { definition }\end{array}$ & $\begin{array}{l}\text { eroscheda } \\
\text { " coefficier } \\
\text { roduct ma } \\
\text { ESSIONAL } \\
1993 \text { onwo } \\
9 \text { onward } \\
\text { growth rc } \\
\text { er of deva } \\
\text { dded at the } \\
\text { DYMENT Tc }\end{array}$ & $\begin{array}{l}\text { of the err } \\
\text { atistically s } \\
\text { competitio } \\
\text { ial dummy } \\
r \text { the coun } \\
\text { e countries } \\
\text { f the expc } \\
\text { ns that a } \\
\text { orial level; } \\
\text { mploymen }\end{array}$ & $\begin{array}{l}\text { erm and ir } \\
\text { icant at } 1 \% \\
\text { xcluding } p \\
\text { iable that } \\
\text { that ente } \\
\text { t enter the } \\
\text { oods defl } \\
\text { ntry that } \\
\text { OR EXPENS } \\
\text { the sectori }\end{array}$ & $\begin{array}{l}\text { ing country, } \\
\text { o, } 10 \% \text { level, } \\
\text { ownership; } \\
\text { ls } 1 \text { for the } \\
\text { EU's Single } \\
\text { U. COMPET1 } \\
\text { relative to } \\
\text { nged to the } \\
\text { bor costs or } \\
\text { vel. See also }\end{array}$ \\
\hline
\end{tabular}

Second, in Table 4, we augment the specifications of Table 3 with several macroeconomic and political controls. 
Table 4 - Other Determinants of Product Markets Reforms (Countries Indicators)

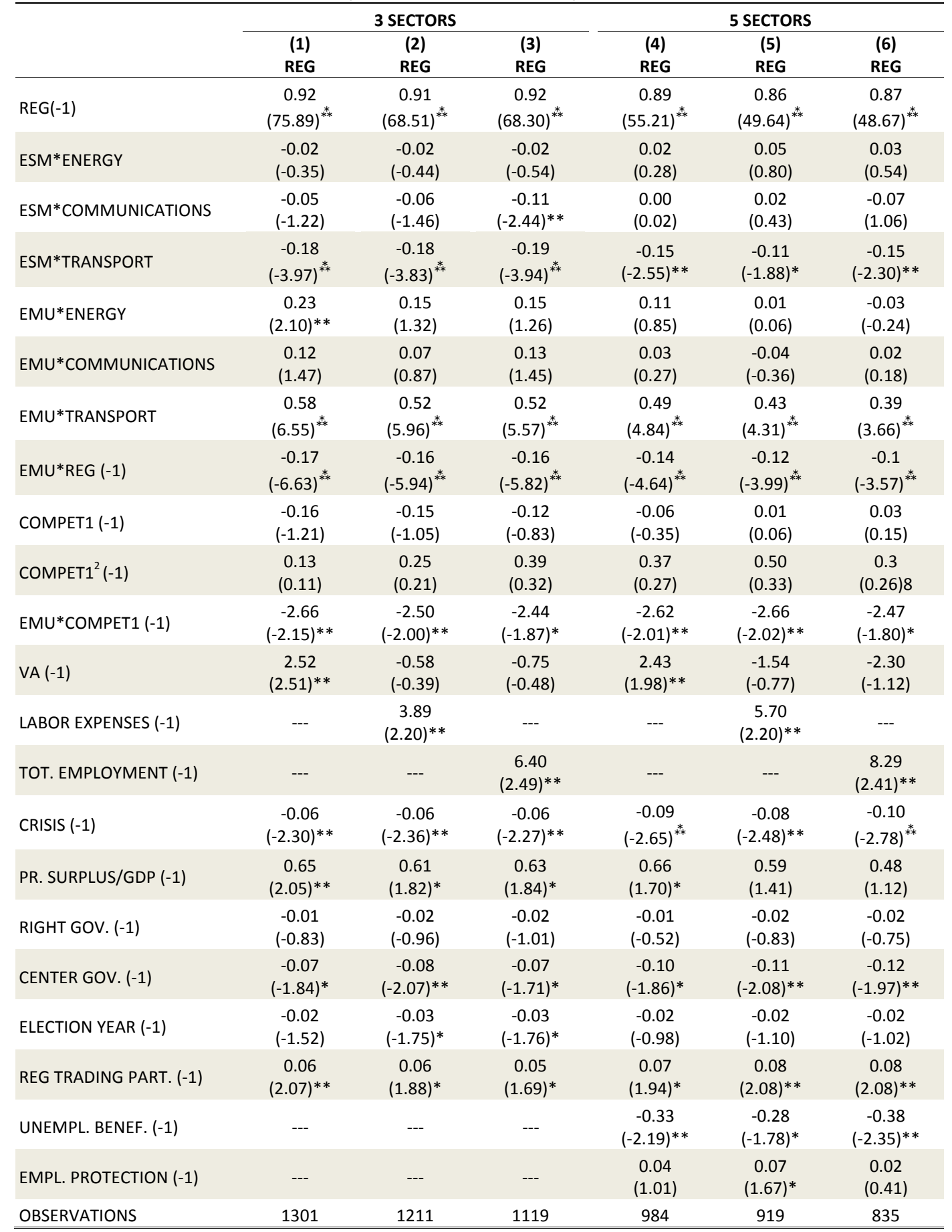

Notes: GLS regressions allowing for heteroschedasticity and including country, sector and time dummies. T-statisitcs in parenthesis. $*^{*}, * *, *$ coefficients statistically significant at $1 \%, 5 \%, 10 \%$ level, respectively. CRISIS dummy variable equal to 1 when the output gap (defined as the difference of actual output to potential) is below the 90th percentile of the output gap empirical density; PRIMARY SURPLUS/GDP: Primary deficit as a share of GDP; RIGHT GOV dummy variable that equals 1 if the government is led by a right oriented party; CENTER GOV dummy variable that equals 1 if the government is led by a center oriented party; ELECTION YEAR: dummy variable that equals 1 if (parliamentary or presidential) elections were held during that year; REG TRADING PARTNERS average of the value of the indicators REG for the trading partners; UNEMPLOYMENT BENEFIT unemployment benefit replacement rate for low-income workers in their 1st year of unemployment; EMPLOYMENT PROTECTION summary indicator of the stringency for employment protection legislation. See Notes to Table 3 and Appendix for the exact definition of all the variables included in the regressions. 
We investigate the "crisis" hypothesis, the role of the countries' fiscal conditions, the timing of reforms in relation to the electoral cycle, the interaction between reforms in the product and labor markets and the effect of reforms occurring in trading partners' countries. All variables are measured at time $t-1$, both to allow for the fact that it may take some time until governments react to macroeconomic events and to reduce the possibility of reverse causality in our estimates. Several results are worth noting. First, the results on EMU shown thus far are robust to the inclusion of the additional control variables. Second, we find evidence that deregulation reforms occur in country-years in which the output gap (defined as the difference of actual output to potential) is below the 90th percentile of the output gap empirical density (equal to $-3.4 \%$ ). This gives some support to the crisis hypothesis, namely that reforms are more likely to occur in bad times. Third, the higher the primary deficit as a share of GDP, the lower the level of regulation, indicating that reforms' blockers may be less powerful when they feel that public finances are also in trouble and that liberalizing the economy can help both in boosting growth and maybe in reducing the likelihood of further increases in taxes or cutting in spending. Fourth, we find some evidence that product market reforms happen at the beginning of the political term (right after an election), but this result is not particularly robust to specification changes. Fifth, deregulation in trading partners fosters deregulation at home. This result is consistent with the evidence in Hoj et al (2006).

Finally, we looked into the interaction between labor market reforms and product market reforms. Specifically, our estimates show that an increase in unemployment benefits leads to lower regulation in product markets, while a decrease in the employment protection index is associated with less regulation of product markets (but the coefficient is significant at the $10 \%$ level only in column 5).

Product market liberalization reforms seem easier to implement if workers receive some kind of protection in the form of social insurance. As mentioned above, workers of the incumbent firms are more likely to become unemployed and lose in the short run from deregulation. Hence, they can be more willing to bear the short-run costs once the generosity of unemployment benefits increases than otherwise. Fiori et al. (2007) find that labor market reforms do not Granger-cause product market reforms. However, their labor market indicator is the principal component of unemployment benefits and employment protection. Results in Table 4 show that the two variables have opposite effects on regulation in product market. Hence, considering a combination of the two variables may prevent one from detecting any effect of labor market regulation on product market regulation. 


\subsection{Endogeneity of Euro Membership}

The decision to join the ESM and especially to adopt the Euro is, of course, not an exogenous variable. In order to investigate this issue, we have re-estimated Table 1 using an instrumental variable procedure. First, we have estimated, with a probit model, the probability that a certain country adopts the Euro. The choice of the right-hand side variable is based upon the gravity literature on trade and the literature on currency unions. ${ }^{16}$ The specification, described in detail in Alesina et al. (2008), is meant to capture that: i) countries that trade more with each other should be more likely to choose to be part of the same common currency area; ii) the higher the correlation of the business cycle frequency (output and prices), the more likely it is that two countries will choose to join the union; and iii) the higher past inflation, the more likely it is that a country will join the union. In fact, the more two countries trade with each other, the more they benefit from a common currency. The more correlated are their business cycles, the lower the costs of a simple monetary policy. Finally a history of high inflation makes a monetary anchor especially effective. We find support, with regard to EMU, for the first two effects but not for the third. ${ }^{17}$ This is not surprising, since the monetary anchor argument certainly did not apply to low-inflation members, e.g., Germany and France.

We then use the estimated probability of joining the union as an instrumental variable for Table 1. The results, shown in Alesina et al. (2008), indicate that the coefficients of interests on EMU in Column 1 of Table 1 are generally robust to this IV procedure. We have investigated all the specifications of Table 1 with various degrees of success. In some cases, the IV results remain significant, while in some cases the standard errors are too big for statistical significance. As we discussed in the Introduction, we are not convinced that the decision to enter the Euro area or not was exogenous only (or mainly) to economic variables. Political consideration seemed crucial, and therefore it is hard to measure the decision of whether to join with an instrument.

\section{Labor Market: the Evidence}

\subsection{The Data}

In order to investigate the determinants of labor market regulation, we consider two time-varying measures for 21 OECD countries for the period

\footnotetext{
${ }^{16}$ See Alesina et al. (2002) in particular.

${ }^{17}$ Also Rose (2000) find a significant and negative impact of the inflation rate on the probability of joining a currency union.
} 
1985-2003. These two measures capture the degree of employment protection related to the firing decisions and the level of insurance provided to the unemployed, respectively. Data on the former measures are coded and collected by the OECD and described in the OECD Employment Outlook (2004). The latter data are also collected at the OECD, Benefits and Wages (several issues); since original data are available only for odd years, data for even years have been obtained by linear interpolation.

The indicator on employment protection ranges from 0 to 6 (from least to most restrictive) and measures the restrictions placed on the firing processes by both labor legislation and collective bargaining agreements. This index includes an assessment of the legislative provisions, as well as the enforcement dimension, as they provide a measure of the judicial practices and court interpretations of legislative and contractual rules. This indicator is also provided separately for regular and temporary workers.

For the regular workers, the indicator on the employment protectory regulation has three main components: i) difficulty of dismissal, i.e., legislative provisions setting conditions under which a dismissal is "justified" or "fair;" ii) procedural inconveniences that the employer may face when starting the dismissal process; and iii) notice and severance pay provisions. The index also provides a measure of the regulation of fixedterm contracts and temporary work agencies. This is intended to measure the restrictions on the use of temporary employment by firms with respect to the type of work for which these contracts are allowed and their duration. The employment legislation for regular contracts constitutes the core component of the overall summary index of EPL strictness that we use.

The indicator on the level of insurance provided to the unemployed represents the unemployment benefit replacement rate for low-income workers in their 1st year of unemployment. This is measured by the average replacement rate, i.e., the ratio of the unemployment benefit to the last wage, for a worker that earns $66 \%$ of average worker earnings.

\subsection{The Euro and Labor Market Reforms}

As for the product market, all our regressions are estimated with Generalized Least Squares, allowing for heteroschedasticity of the error term, and include the lagged value of the left-hand side variable and country and time dummies.

In Table 5, we consider the generosity of the unemployment benefit, as defined above, to be a measure of labor market regulation. In column 1, we start from the basic specification with only tests for the effects of the European Single Market and of the EURO. 
Table 5 - The Euro and Unemployment Benefits

\begin{tabular}{|c|c|c|c|c|c|c|}
\hline & $\begin{array}{c}(1) \\
\text { UNEMPL. } \\
\text { BENEFIT }\end{array}$ & $\begin{array}{c}\text { (2) } \\
\text { UNEMPL. } \\
\text { BENEFIT }\end{array}$ & $\begin{array}{c}\text { (3) } \\
\text { UNEMPL. } \\
\text { BENEFIT }\end{array}$ & $\begin{array}{c}\text { (4) } \\
\text { UNEMPL. } \\
\text { BENEFIT }\end{array}$ & $\begin{array}{c}\text { (5) } \\
\text { UNEMPL. } \\
\text { BENEFIT }\end{array}$ & $\begin{array}{c}(6) \\
\text { UNEMPL. } \\
\text { BENEFIT }\end{array}$ \\
\hline UNEMPL. BENEF. (-1) & $\begin{array}{c}0.93 \\
(38.57)^{* *}\end{array}$ & $\begin{array}{c}0.93 \\
(38.58)^{* *}\end{array}$ & $\begin{array}{c}0.94 \\
(38.49)^{* *}\end{array}$ & $\begin{array}{c}0.93 \\
(36.90)^{* * *}\end{array}$ & $\begin{array}{c}0.93 \\
(36.02)^{* *}\end{array}$ & $\begin{array}{c}0.93 \\
(35.80)^{* *}\end{array}$ \\
\hline ESM & $\begin{array}{c}0.00 \\
(1.43)\end{array}$ & $\begin{array}{c}0.00 \\
(1.42)\end{array}$ & $\begin{array}{l}-0.01 \\
(-1.44)\end{array}$ & $\begin{array}{l}0.00 \\
(0.77)\end{array}$ & $\begin{array}{l}0.00 \\
(0.62)\end{array}$ & $\begin{array}{l}0.00 \\
(0.78)\end{array}$ \\
\hline EMU & $\begin{array}{c}0.01 \\
(2.03)^{* *}\end{array}$ & $\begin{array}{c}0.01 \\
(1.35)\end{array}$ & $\begin{array}{c}0.01 \\
(1.62)\end{array}$ & $\begin{array}{c}0.01 \\
(2.00)^{* *}\end{array}$ & $\begin{array}{c}0.01 \\
(2.35)^{* *}\end{array}$ & $\begin{array}{c}0.01 \\
(2.29)^{* *}\end{array}$ \\
\hline EMU*UNEMPL. BENEF. $(-1)$ & --- & $\begin{array}{c}-0.01 \\
(-0.45)\end{array}$ & --- & --- & --- & --- \\
\hline COMPET $(-1)$ & --- & --- & $\begin{array}{c}-0.01 \\
(-0.63)\end{array}$ & --- & --- & --- \\
\hline $\operatorname{COMPET1}^{2}(-1)$ & --- & --- & $\begin{array}{l}-0.04 \\
(-0.26)\end{array}$ & --- & --- & --- \\
\hline EMU*COMPET1 (-1) & --- & --- & $\begin{array}{c}-0.11 \\
(-1.27)\end{array}$ & --- & --- & --- \\
\hline CRISIS (-1) & --- & --- & --- & $\begin{array}{c}0.00 \\
(0.23)\end{array}$ & $\begin{array}{l}0.00 \\
(0.23)\end{array}$ & $\begin{array}{l}0.00 \\
(0.34)\end{array}$ \\
\hline PR.SURPLUS/GDP (-1) & --- & --- & --- & $\begin{array}{c}0.04 \\
(1.18)\end{array}$ & $\begin{array}{c}0.03 \\
(0.76)\end{array}$ & $\begin{array}{l}0.03 \\
(0.76)\end{array}$ \\
\hline RIGHT GOV (-1) & --- & --- & --- & $\begin{array}{l}0.00 \\
(0.12)\end{array}$ & $\begin{array}{l}0.00 \\
(0.48)\end{array}$ & $\begin{array}{c}0.00 \\
(0.32)\end{array}$ \\
\hline CENT. GOV $(-1)$ & --- & --- & --- & $\begin{array}{l}-0.01 \\
(-0.99)\end{array}$ & $\begin{array}{l}-0.01 \\
(-0.91)\end{array}$ & $\begin{array}{c}-0.01 \\
(-1.11)\end{array}$ \\
\hline ELECT. YR (-1) & --- & --- & --- & $\begin{array}{l}0.00 \\
(0.16)\end{array}$ & $\begin{array}{l}0.00 \\
(0.05)\end{array}$ & $\begin{array}{l}0.00 \\
(0.15)\end{array}$ \\
\hline EMPL. PROTECTION (-1) & --- & --- & --- & --- & $\begin{array}{c}0.00 \\
(0.46)\end{array}$ & $\begin{array}{l}0.00 \\
(0.52)\end{array}$ \\
\hline $\begin{array}{l}\text { UNEMPLOYMENT BENEFIT } \\
\text { TRADING PARTNERS }(-1)\end{array}$ & --- & --- & --- & --- & $\begin{array}{c}-0.10 \\
(-2.29)^{* *}\end{array}$ & $\begin{array}{c}-0.10 \\
(-2.39)^{* *}\end{array}$ \\
\hline PMKT REGUL. $(-1)$ & --- & --- & --- & --- & $\begin{array}{c}0.00 \\
(1.38)\end{array}$ & $\begin{array}{l}0.00 \\
(0.45)\end{array}$ \\
\hline PMKT REGUL. (-2) & --- & --- & --- & --- & --- & $\begin{array}{c}0.01 \\
(1.59)\end{array}$ \\
\hline OBSERVATIONS & 378 & 378 & 360 & 366 & 362 & 362 \\
\hline
\end{tabular}

Notes: Generalized least squares regressions allowing for heteroschedasticity of the error term and including country, sector and time dummies. T-statisitcs in parenthesis. $*_{* *}^{*}, * *, *$ coefficients statistically significant at $1 \%, 5 \%, 10 \%$ level, respectively. UNEMPLOYMENT BENEFIT TRADING PARTNERS average of the value of the indicator UNEMPLOYMENT BENEFIT for the trading partners; PMKT REGULAT country average value of the sectorial indicator REG. See Notes to Tables 3 and 4 and Appendix for the exact definition of all the variables included in the regressions.

We then add the interaction of EMU with the lagged value of the depended variable (column 2), our measures of competition (column 3), and additional possible explanatory variables encountered in the literature, such as economic crisis and fiscal and political variables (column 4). Finally, columns 5 and 6 report the results of the regressions that include the effects of the lagged variable of regulation in the product market, the alternative variable of regulation in the labor market (EPL) and the level of unemployment benefits in the trading partners. The results show that, while the ESM had no impact on this measure of labor 
market regulation, the introduction of the EURO led to an increase in the generosity of the unemployment benefit. No other variable shows any explanatory power, with the exception of the level of unemployment benefits in the trading partners, which, however, presents a puzzling result, since more $U B$ in trading partners is associated with less $U B$ in the home country.

Table 6 - The Euro and Employment Protection

\begin{tabular}{|c|c|c|c|c|c|c|}
\hline & $\begin{array}{c}\text { (1) } \\
\text { EMPLOYMENT } \\
\text { PROTECTION }\end{array}$ & $\begin{array}{c}\text { (2) } \\
\text { EMPLOYMENT } \\
\text { PROTECTION }\end{array}$ & $\begin{array}{c}\text { (3) } \\
\text { EMPLOYMENT } \\
\text { PROTECTION }\end{array}$ & $\begin{array}{c}\text { (4) } \\
\text { EMPLOYMENT } \\
\text { PROTECTION }\end{array}$ & $\begin{array}{c}\text { (5) } \\
\text { EMPLOYMENT } \\
\text { PROTECTION }\end{array}$ & $\begin{array}{c}(6) \\
\text { EMPLOYMENT } \\
\text { PROTECTION }\end{array}$ \\
\hline $\begin{array}{l}\text { EMPL. PROTECTION } \\
(-1)\end{array}$ & $\begin{array}{c}0.93 \\
(31.35)^{* * *}\end{array}$ & $\begin{array}{c}0.92 \\
(31.08)^{* *}\end{array}$ & $\begin{array}{c}0.93 \\
(31.51)^{* * *}\end{array}$ & $\begin{array}{c}0.92 \\
(30.70)^{* *}\end{array}$ & $\begin{array}{c}0.92 \\
(30.77)^{* *}\end{array}$ & $\begin{array}{c}0.92 \\
(30.68)^{* * *}\end{array}$ \\
\hline ESM & $\begin{array}{l}-0.01 \\
(-0.97)\end{array}$ & $\begin{array}{l}-0.01 \\
(-0.95)\end{array}$ & $\begin{array}{c}-0.02 \\
(-1.07)\end{array}$ & $\begin{array}{c}0.00 \\
(0.28)\end{array}$ & $\begin{array}{c}0.00 \\
(0.24)\end{array}$ & $\begin{array}{c}0.00 \\
(0.24)\end{array}$ \\
\hline EMU & $\begin{array}{l}-0.01 \\
(-0.66)\end{array}$ & $\begin{array}{c}0.04 \\
(0.79)\end{array}$ & $\begin{array}{c}0.00 \\
(0.04)\end{array}$ & $\begin{array}{l}-0.02 \\
(-0.89)\end{array}$ & $\begin{array}{c}0.00 \\
(0.23)\end{array}$ & $\begin{array}{l}-0.01 \\
(-0.26)\end{array}$ \\
\hline $\begin{array}{l}\text { EMU* EMPL. } \\
\text { PROTECTION (-1) }\end{array}$ & --- & $\begin{array}{l}-0.02 \\
(-1.13)\end{array}$ & --- & --- & --- & --- \\
\hline COMPET1 (-1) & --- & --- & $\begin{array}{l}0.00 \\
(0.06)\end{array}$ & --- & --- & --- \\
\hline $\operatorname{COMPET1}^{2}(-1)$ & --- & --- & $\begin{array}{c}0.17 \\
(0.34)\end{array}$ & --- & --- & --- \\
\hline EMU*COMPET1 (-1) & --- & --- & $\begin{array}{c}0.51 \\
(0.94)\end{array}$ & --- & --- & --- \\
\hline CRISIS (-1) & --- & --- & --- & $\begin{array}{l}-0.01 \\
(-0.91)\end{array}$ & $\begin{array}{l}-0.01 \\
(-0.46)\end{array}$ & $\begin{array}{l}-0.01 \\
(-0.46)\end{array}$ \\
\hline PR.SURPL./GDP (-1) & --- & --- & --- & $\begin{array}{c}0.00 \\
(0.01)\end{array}$ & $\begin{array}{l}-0.01 \\
(-0.07)\end{array}$ & $\begin{array}{c}-0.01 \\
(-0.08)\end{array}$ \\
\hline RIGHT GOV (-1) & --- & --- & --- & $\begin{array}{c}-0.01 \\
(-1.45)\end{array}$ & $\begin{array}{l}-0.01 \\
(-0.99)\end{array}$ & $\begin{array}{c}-0.01 \\
(-1.00)\end{array}$ \\
\hline CENT. GOV (-1) & --- & --- & --- & $\begin{array}{c}0.00 \\
(0.16)\end{array}$ & $\begin{array}{c}0.00 \\
(0.11)\end{array}$ & $\begin{array}{c}0.00 \\
(0.12)\end{array}$ \\
\hline ELECT. YR (-1) & --- & --- & --- & $\begin{array}{c}0.00 \\
(0.51)\end{array}$ & $\begin{array}{c}0.00 \\
(0.37)\end{array}$ & $\begin{array}{c}0.00 \\
(0.38)\end{array}$ \\
\hline UNEMPL. BENEF. $(-1)$ & --- & --- & --- & --- & $\begin{array}{l}-0.13 \\
(-1.58)\end{array}$ & $\begin{array}{l}-0.13 \\
(-1.53)\end{array}$ \\
\hline $\begin{array}{l}\text { EMPL PROTECT } \\
\text { TRADING PARTNERS } \\
(-1)\end{array}$ & --- & --- & --- & --- & $\begin{array}{c}0.03 \\
(1.46)\end{array}$ & $\begin{array}{c}0.03 \\
(1.46)\end{array}$ \\
\hline PMKT REGUL. (-1) & --- & --- & --- & --- & $\begin{array}{l}-0.01 \\
(-0.47)\end{array}$ & $\begin{array}{l}0.00 \\
(0.20)\end{array}$ \\
\hline PMKT REGUL. $(-2)$ & --- & --- & --- & --- & --- & $\begin{array}{c}0.00 \\
(0.07)\end{array}$ \\
\hline OBSERVATIONS & 373 & 373 & 355 & 362 & 362 & 362 \\
\hline
\end{tabular}

When using the degree of employment protective legislation $(E P L)$ as a measure of labor market regulation, as in table 6, we do not find any effect 
of EMU - or any other plausible explanatory variable - on labor market reforms. More generally, we found that this index of labor market reform moved much less than that of product market, as shown at figure 4 .

Figure 4 - Deregulation in Product and Labor Markets

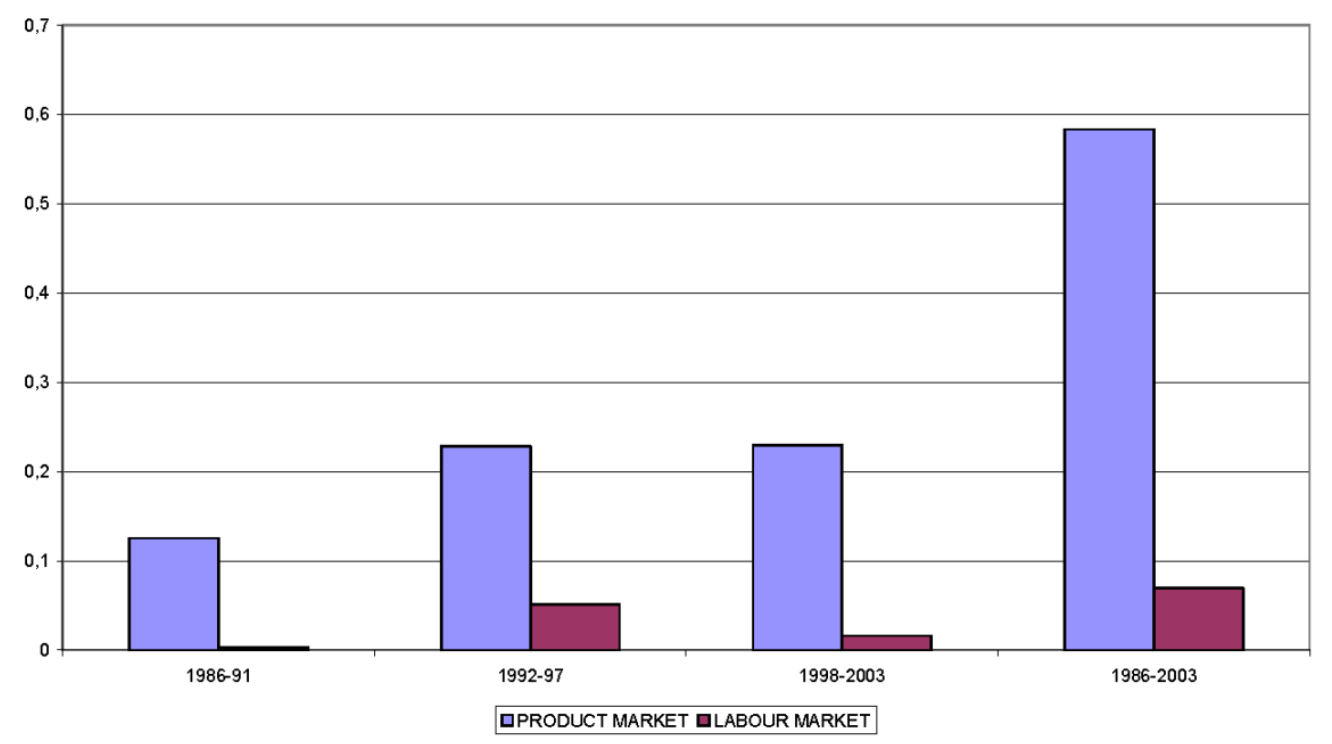

\subsection{Additional Evidence}

The indicator of labor market reform used in the previous section may give an overly narrow view of the evolution of labor markets in Europe. These indicators of flexibility refer only to the "primary" labor market. But two other factors, related to each other, have changed. One has been the development of a vast labor market in several countries based on temporary contracts with very few, if any, of the rigidities of the primary labor market. For instance, much of the increase in employment reported in France, Italy and Spain has occurred in this secondary market. The second change is that, in the last ten or fifteen years, several European countries seem to have experienced a substantial amount of wage moderation. In Table 7, we investigated whether the adoption of the Euro has contributed to achieving wage moderation in these seemingly unreformed labor markets.

This is, of course, important as an indicator of second-round effects: i.e., whether or not inflationary shocks get a "second-round" boost from wage increases. This table shows that the countries that joined the EMU in 1999 have experienced a significant increase in wage moderation in the period leading up to the common currency: i.e., between 1993 and 1999. After this period, there is no evidence of an additional effect of Euro adoption on the degree of wage moderation. These results are consistent with the fact that, in preparation for EMU membership, many countries had to "put their 
houses in order." This meant inflation reduction and fiscal rigor (in areas including public salaries).

Table 7-The Euro and Wage Moderation

\begin{tabular}{|c|c|c|}
\hline & $\begin{array}{c}\text { (1) } \\
\text { NOMINAL WAGE GROWTH }\end{array}$ & $\begin{array}{c}\text { (2) } \\
\text { NOMINAL WAGE GROWTH }\end{array}$ \\
\hline NOMINAL WAGE GROWTH LAGGED & $\begin{array}{c}0.48 \\
(10.43)^{* *}\end{array}$ & $\begin{array}{c}0.47 \\
(10.12)^{* * *}\end{array}$ \\
\hline LAGGED INFLATION & $\begin{array}{c}0.22 \\
(3.69)^{* *}\end{array}$ & $\begin{array}{c}0.24 \\
(3.91)^{* *}\end{array}$ \\
\hline ESM & $\begin{array}{c}-0.01 \\
(-2.50)^{* *}\end{array}$ & --- \\
\hline EMU 93-98 & --- & $\begin{array}{c}-0.01 \\
(-2.90)^{* *}\end{array}$ \\
\hline EMU 99-03 & $\begin{array}{c}0.00 \\
(0.89)\end{array}$ & $\begin{array}{c}-0.01 \\
(-1.50)\end{array}$ \\
\hline EU-NO EMU 93-03 & --- & $\begin{array}{l}-0.01 \\
(-1.33)\end{array}$ \\
\hline OBSERVATIONS & 508 & 508 \\
\hline
\end{tabular}

More specifically, in column 1 of Table 7 , the dependent variable is the growth of nominal wages. On the right-hand side, in addition to the lagged dependent variable, we have lagged inflation and our variables capturing simple market membership and EMU membership. The former (but not the latter) has a negative and statistically significant coefficient, indicating, at least at first sight, an effect of simple market membership on wage moderation. However, in Column 2, we show that this result is driven by the countries' membership of the simple market and their preparation to join the EMU and attempts to achieve convergence criteria. In fact, we added a dummy for EMU countries in the run up to the Euro (1993-1998) and another one after they adopted the single currency. As this column shows, the pre-Euro dummy variable has a significant negative coefficient. Meanwhile, the coefficient on the post-Euro period is insignificant. We also investigated possible differential effects between EMU and non-EMU countries relative to the effects of (lagged) inflation, but we found no differences.

\section{Conclusions}

Our statistical analysis suggests that the adoption of the Euro has had a significant effect in promoting the adoption of product market reforms, at least in some sectors. 
There are three possible interpretations of the results. One is that it is simply a coincidence: some countries decided to reform right at the end of the nineties, and this time period happened to coincide with the adoption of the Euro. The second interpretation is that the Euro did indeed have an effect in promoting liberalization by eliminating the palliative of competitive devaluations. Firms found themselves losing competitiveness and became more vocal in demanding liberalization in sectors which were providing intermediate goods and services (including non-tradable ones) in order to keep their costs low. A third story, related to the second, is that the Euro did not matter that much economically per se but that it was used as a political tool by reformers to argue that countries belonging to the Euro area needed structural reform; in other words, the Euro was used as a justification to promote a product market reform agenda.

One should be worried about the possibility of spurious correlations because of the relatively small number of countries involved in the tests; however, the results do appear quite robust to a battery of econometric tests. It is hard to entirely disentangle the role of actual economic pressures introduced by the Euro and the political rhetoric associated with it, but certainly the results of our econometric exercise have moved us from our prior assumptions towards believing that the Euro might indeed have had an effect in, if not promoting, at least weakening the opposition to product market reforms. Future work should take some further steps towards trying to disentangle these three alternatives. One step in this direction would be to focus on where the political and economic pressure to liberalize certain sectors came from. ${ }^{18}$

The adoption of the Euro does not seem to have had much of an effect in promoting labor market reforms, at least in the primary labor market sector: in general, labor markets have proceeded more slowly and tentatively than product markets. However, a secondary labor market with temporary labor contracts has grown in a few countries which did not reform the primary labor market. In addition, the run up Euro adoption has led to some wage moderation. This timing has led us to consider the question of whether product market reform should indeed precede labor market liberalization. We find that regulation decreases when value added and labor costs of the sector fall, i.e., when a sector's rents decrease, and that product markets are deregulated in countrysectors-years with lower employment. Hence, in less labor-intensive sectors, governments can meet less resistance and can more easily implement deregulation measures. However, we also find that product

\footnotetext{
${ }^{18}$ Interestingly, energy, the sector that was mostly affected by the introduction of the EURO, was found by Barone and Cingano (2008) to be the service sector, whose liberalization has the most beneficial effects on the growth rate of the downstream manufacturing sectors.
} 
market deregulation is easier to implement when unemployment subsidies are more generous and more difficult when there are higher firing costs, which interfere with market reallocations. Therefore, the type of labor market policies more prone to facilitating product market reforms are those in which the workers are protected with unemployment subsidies but specific jobs are not, making the (re)matching between firms and workers easier. Labor market reforms are multidimensional in nature and are often quite complex and difficult to capture with one macro indicator. Also, several countries in the Euro area have two separate markets: the traditional and highly regulated market and a second, much more flexible, one based on temporary contracts. Further investigation into the role of the Euro in promoting labor market reform is an excellent topic for future research. 


\section{References}

Alesina, A., Ardagna, S., \& Galasso, V. (2008). The Euro and Structural Reforms. NBER Working Paper 14479. Cambridge, MA: NBER.

Alesina, A., Ardagna, S., \& Trebbi, F. (2006). Who Adjusts and When? On the Political Economy of Stabilizations. IMF Staff Papers 53 (Special Issue), 1-49.

Alesina, A. \& Barro, R. (2002). Currency Unions. Quarterly Journal of Economics, 117(2), 409-436. doi:10.1162/003355302753650283

Alesina, A., Barro, R., \& Tenreyro, S. (2002). Optimal Currency Areas. NBER Macroeconomic Annual, 17, 301-356, Cambridge, MA: NBER.

Alesina, A., \& Drazen, A. (1991). Why Are Stabilizations Delayed? American Economic Review, 81(5), 1170-1188.

Alesina, A., \& Giavazzi, F. (2006). The Future of Europe. Reform or Decline. Cambridge, MA: MIT Press.

Alesina, A., \& Perotti, R. (2004). The European Union: A politically incorrect view. Journal of Economic Perspectives, 18(4), 27-48. doi:10.1257/0895330042632780

Alesina, A., Perotti, R., \& Tavares, J. (1998). The Political Economy of Fiscal Adjustments. Brookings Papers on Economic Activity, 1998(1), 197-266. doi:10.2307/2534672

Alesina, A., Roubini, N., \& Cohen, G. (1997). Political Cycles and the Macroeconomy. Cambridge, MA: MIT Press.

Barone, G., \& Cingano, F. (2008). Service Regulation and Growth: Evidence from OECD Countries. Temi di discussione (Working papers) 675. Bank of Italy, Economic Research Department.

Bean, C. (1998). The Interaction of Aggregate Demand Policies and Labor Market Reform. Swedish Economic Policy Review, 5(2), 353-382.

Beck, T., Clarke, G., Groff, A., Keefer, P., \& Walsh, P. (2001). New Tools and New Tests in Comparative Political Economy: The Database of Political Institutions. The World Bank Economic Review, 15(1), 165-176. doi:10.1093/wber/15.1.165

Belke, A., Herz, B., \& Vogel, L. (2005). Structural Reform and the Exchange Rate Regime: A Panel Analysis for the World Versus OECD Countries. IZA Discussion Papers 1798. Bonn: Institute for the Study of Labor (IZA).

Bertola, G. (2008). Labor Markets in EMU - What has Changed and What Needs to Change. European Economy. Economic Papers, 338. Brussels: 
European Commission, Directorate-General for Economic and Financial Affairs.

Blanchard, O., \& Giavazzi, F. (2003). The Macroeconomic Effects of Labor and Product Market Deregulation. The Quarterly Journal of Economics, 118(3), 879-907.

Brender, A., \& Drazen, A. (2005). Political Budget Cycles in New and Established Democracies. Journal of Monetary Economics, 52(7), 12711295. doi:10.1016/j.jmoneco.2005.04.004

Bugamelli, M., Schivardi, F., \& Zizza, R. (2010). The Euro and Firm Restructuring. In: Alesina, A. \& Giavazzi, F. (Eds.), Europe and the Euro (pp. 99-138). Chicago: Chicago University Press.

Conway, P., \& Nicoletti, G. (2007). Product Market Regulation in NonManufacturing Sectors of OECD Countries: Measurement and Highlights. OECD Economics Department Working Papers, No. 530. doi: $10.1787 / 362886816127$

Drazen, A., (2000). Political Economy in Macroeconomics. Princeton: Princeton University Press

Drazen, A., \& Grilli, V. (1993). The Benefits of Crises for Economic Reform. American Economic Review, 83(3), 598-607.

Drazen, A., \& Easterly, W. (2001). Do Crises Induce Reform? Simple Empirical Tests of Conventional Wisdom. Economics \& Politics, 13(2), 129-157. doi:10.1111/1468-0343.00087

Duval, R., \& Elmeskov, J. (2005). The Effects of EMU on Structural Reforms in Labour and Product Markets. OECD Economics Department Working Papers, No. 438. doi:10.1787/830757326248

Eichengreen, B. (2010). The Break-up of the Euro-Area. In: Alesina, A., \& Giavazzi, F. (Eds.), Europe and the Euro (pp. 11-51). Chicago: Chicago University Press.

Fatas, A., \& Mihov, I. (2010). The Euro and the Fiscal Policy. In: Alesina, A., \& Giavazzi, F. (Eds.), Europe and the Euro (pp. 287-324). Chicago: Chicago University Press.

Frankel, J. (2010). The Estimated Trade Effects of the Euro: Why Are They Below Those from Historical Monetary Unions among Smaller Countries? In: Alesina, A., \& Giavazzi, F. (Eds.), Europe and the Euro (pp. 169-212). Chicago: Chicago University Press.

Fiori, G., Nicoletti, G., Scarpetta, S., \& Schiantarelli, F. (2007). Employment Outcomes and the Interaction between Product and Labor Market Deregulation: Are They Substitutes or Complements? IZA Discussion Papers 2770. Bonn: Institute for the Study of Labor (IZA). 
Hoj, J., Galasso, V., Nicoletti, G., \& Dang, T.T. (2006). The Political Economy of Structural Reform: Empirical Evidence from OECD Countries. OECD Economics Department Working Papers, No. 501. doi: $10.1787 / 881353527404$

IMF (2004). Fostering Structural Reforms in Industrialized Countries. World Economic Outlook, April, 24-128.

McCallum, J. (1995). National Borders Matter: Canadian-U.S. Regional Trade Patterns. American Economic Review, 85(3), 615-623.

Nicoletti, G., \& Scarpetta, S. (2003). Regulation, Productivity and Growth: OECD Evidence. Economic Policy, 18(36), 9-72.

Nicoletti, G., \& Scarpetta, S. (2005). Product Market Reforms and Employment in the OECD Countries. OECD Economics Department Working Papers, No. 472. doi:10.1787/463767160680

Obstfeld, M. (1997). Europe's Gamble. Brookings Papers on Economic Activity, 28(1997-2), 241-317. doi:10.2307/2534689

Persson, T. (2001). Currency Union and Trade, How Large Is the Treatment Effect? Economic Policy, 16(33), 433-462. doi:10.1111/1468$\underline{0327.00081}$

Rose, A. (2000). One money, one market: the effect of common currencies on trade. Economic Policy, 15(30), 7-46. doi:10.1111/1468-0327.00056

Saint-Paul, G. (1996). Exploring the Political Economy of Labor Market Institutions. Economic Policy, 11(23), 265-315.

Saint-Paul, G. (1999). Assessing the Political viability of Labor Market Reform: the Case of Employment Protection. CEPR Discussion Paper 2136. CEPR Discussion Papers.

Saint-Paul, G. (2000). The Political Economy of Labour Market Institutions. Oxford: Oxford University Press.

Saint-Paul, G., \& Bentolila, S. (2000). Will EMU Increase Eurosclerosis? CEPR Discussion Papers 2423. CEPR Discussion Papers.

Tenreyro, S. (2007). On the Trade Impact of Exchange Rate Volatility. Journal of Development Economics, 82(2), 485-508. doi:10.1016/j.jdeveco.2006.03.007

Thom, R., \& Walsh, B. (2002). The Effect of a Currency Union on Trade: Lessons from the Irish Experience. European Economic Review, 46(6), 1111-1123. doi:10.1016/S0014-2921(01)00203-3 


\section{Appendix: Data Sources and Definitions}

Our data set includes yearly data on 21 OECD countries (Australia, Austria, Belgium, Canada, Switzerland, Germany, Denmark, Spain, Finland, France, the UK, Greece, Ireland, Italy, Japan, the Netherlands, New Zealand, Norway, Portugal, Sweden, and the US) from 1975 to 2003. Here is a list of variables used in our regressions, with their definitions and sources.

REG: Aggregation of the OECD summary indicator of regulatory impediments to product market competition, excluding public ownership, in three or five broad sectors: energy (electricity and gas), communication (telecommunications and post), and transportation (airlines, road freight and railways); and retail and professionals. Data on regulation in professionals are only available in 1996 and 2003 and for retail in 1998 and 2003. Source: Conway and Nicoletti (2007) and Nicoletti and Scarpetta (2003).

ENERGY, COMMUNICATIONS, TRANSPORT, RETAIL and PROFESSIONAL: Sectorial dummy variable that equals 1 for the corresponding sector.

European Single Market (ESM ): Dummy variable that equals 1 for the countries that enter the EU's Single Market Programme after its implementation in 1993.

$E M U$ : Dummy variable that equals 1 for the countries that enter the EMU after its implementation in 1999.

$E M U^{* \prime}$ variable": Interaction between EMU and the corresponding variable.

$E S M^{*}$ "variable": Interaction between Single Market and the corresponding variable.

COMPET1: Indicator of lack of competitiveness at the country-sector-year level for the period 1975-2003 for the energy, communications, and transport sectors, measured as the growth rate of the CPI relative to competitors at $t-1$. Source: OECD Economic Outlook n. 80.

COMPET2: Indicator of lack of competitiveness at the country-sector-year level for the period 1975-2003 for the energy, communications, and transport sectors, measured as the growth rate of the export goods deflators relative to competitors at $\mathrm{t}$ - 1. Source: OECD Economic Outlook n. 80.

N. OF DEVALUTIONS FROM 1979-1993: Number of devaluations that a country that belonged to the European Monetary System did from 1979 to 1993.

$V A$ : Value added for the three sectors: Energy (electricity, gas and water), Communications (communications and posts), and Transport (transport and storage). It measures the sector contribution to national GDP, calculated as the difference between Production and Intermediate inputs. Source: OECD STAN database for Industrial Analysis, Revision 3 (ISIC Rev. 3)

LABOR EXPENSES: Labor costs or compensation of employees in the three sectors above. It includes wages and salaries of employees paid by producers, as 
well as supplements such as contributions to social security, private pensions, health insurance, life insurance and similar schemes. Source: OECD STAN database for Industrial Analysis, Revision 3 (ISIC Rev. 3)

TOT. EMPLOYMENT: Total Employment in the three sectors above. Source: OECD STAN database for Industrial Analysis, Revision 3 (ISIC Rev. 3)

CRISIS: Dummy variable equal to 1 when the output gap (defined as the difference of actual output to potential) is below the 90th percentile of the output gap empirical density (equal to $-3.4 \%$ ). Source: OECD Economic Outlook database.

PR. SURPLUS/GDP: Primary deficit as a share of GDP. Source: OECD Economic Outlook database.

RIGHT GOV.: Dummy variable that equals 1 if the government is led by a Right party or coalition (Right: parties that are defined as conservative, Chris- tian democratic, or right-wing). Source: Database of Political Institutions (DPI) of the World Bank, compiled by Beck, Clarke, Groff, Keefer, and Walsh (2001)

CENTER GOV.: Dummy variable that equals 1 if the government is led by a Center party or coalition (parties that are defined as centrist or when party position can best be described as centrist, e.g., party advocates strengthening private enterprise in a social-liberal context). Source: Database of Political Institutions (DPI) of the World Bank, compiled by Beck, Clarke, Groff, Keefer, and Walsh (2001).

ELECTION YEAR: Dummy variable that equals 1 if (parliamentary or presidential) elections were held during that year. Source: Database of Political Institutions (DPI) of the World Bank, compiled by Beck, Clarke, Groff, Keefer, and Walsh (2001).

REG TRADING PARTNERS: Average of the value of the indicators REG for the trading partners. Source: Conway and Nicoletti (2007) and Nicoletti and Scarpetta (2003) and OECD STAN database for Industrial Analysis, Revision 3 (ISIC Rev. 3).

UNEMPL. BENEF.: Unemployment benefit replacement rate for low-income workers in their 1st year of unemployment. This is measured by the average replacement rate, i.e., the ratio of the unemployment benefit to the last wage, for a worker that earns $66 \%$ of average worker earnings. Source: OECD, Benefits and Wages.

EMPL. PROTECTION: OECD summary indicator of the stringency for Employment Protection Legislation for all contract, defined as the average of values for the Indefinite contract (regular) workers and the Fixed-term contract (temporary) workers. Source: OECD, Employment Outlook 2004.

UNEMPLOYMENT BENEFIT TRADING PARTNERS: Average of the value of the indicator UNEMPL. BENEF. for the trading partners. Source: OECD, Benefits and Wages and OECD STAN database for Industrial Analysis, Revision 3 (ISIC Rev. 3). 
PMKT REGUL. (-1 and -2): country average value (lagged one and two periods) of the sectorial indicator REG.

EMPLOYMENT PROTECTION TRADINGPARTNERS: Average of the value of the indicators EMPLOYMENT PROTECTION for the trading part- ners. Source: OECD, Employment Outlook 2004 and OECD STAN database for Industrial Analysis, Revision 3 (ISIC Rev. 3). 